\title{
New Oxidized ent-Kaurane and ent-Norkaurane Derivatives from Kaurenoic Acid
}

\author{
Ronan Batista, ${ }^{*, a, c}$ Pablo A. García, Maria A. Castro, ${ }^{b}$ José M. Miguel del Corral, ${ }^{b}$ \\ Arturo San Feliciano ${ }^{b}$ and Alaíde B. de Oliveira ${ }^{c}$ \\ ${ }^{a}$ Departamento de Estudos Básicos e Instrumentais, Universidade Estadual do Sudoeste da Bahia, \\ $B R$ 415, km 03, 45.700-000 Itapetinga-BA, Brazil \\ ${ }^{b}$ Departamento de Química Farmacéutica, Facultad de Farmacia, Universidad de Salamanca, \\ 37007 Salamanca, Spain \\ ${ }^{c}$ Departamento de Produtos Farmacêuticos, Faculdade de Farmácia, Universidade Federal de \\ Minas Gerais, Av. Antônio Carlos, 6.627, 31.270-901 Belo Horizonte-MG, Brazil
}

\begin{abstract}
Novos derivados oxidados ent-caurânicos e ent-norcaurânicos foram sintetizados a partir do ácido caurenóico. Todos os produtos obtidos foram caracterizados espectroscopicamente.
\end{abstract}

New oxidized ent-kaurane and ent-norkaurane derivatives were synthezised starting from kaurenoic acid. The spectroscopic characterization of all compounds is reported.

Keywords: diterpenes, kaurenoic acid, ent-kaurane and ent-norkaurane derivatives, PDC oxidation

\section{Introduction}

Kauranes are an important class of diterpenes containing a rigid tetracyclic skeleton and exhibiting a wide variety of biological activities such as antitumor, anti-HIV, trypanocidal and antimicrobial, among others. ${ }^{1}$ For this reason, the development of new strategies for the synthesis of novel kaurane derivatives may be considered as one of the interesting challenges in Chemistry of Natural Products. Indeed, many naturally occurring bioactive kauranes have been transformed using chemical and microbial methods in order to improve their bioactivity. ${ }^{2,3}$

Kaurenoic acid (ent-kaur-16-en-19-oic acid, 1) is an intermediate in the biosynthesis of numerous plants and fungal secondary metabolites, including gibberellins, the phytohormones involved in the regulation of growth and development of higher plants, ${ }^{1}$ found abundantly in some Brazilian species as Wedelia paludosa D.C. (Asteraceae), Xylopia frutescens and Annona glabra (Annonaceae). ${ }^{4}$

We have reported, in a previous phytochemical study of Wedelia paludosa D.C., the isolation of kaurenoic acid (1) as the main ent-kaurane diterpene in this species, besides other related diterpenes and triterpenes as minor constituents. ${ }^{4,5}$ Among more recently biological activities

*e-mail: ronbatis2004@gmail.com reported for $\mathbf{1}$, we can stand out the antimicrobial, ${ }^{6}$ antiplatelet aggregation, ${ }^{7}$ analgesic, ${ }^{8}$ antifungal, ${ }^{3,9}$ smooth muscle relaxant, ${ }^{10}$ hypoglycemic, ${ }^{11}$ cytotoxic and embryotoxic ${ }^{12}$ effects.

Considering these biological effects, along with our special interest on novel kaurane derivatives, we carried on the synthesis of ent-kaurane aldehydes methyl ent17-oxokauran-19-oate (4) and methyl ent-17-oxo-16ßkauran-19-oate (5), important as semisynthetic coupling intermediates, starting from kaurenoic acid (1). In addition, we describe here, for the first time, the synthesis of methyl ent-17-oxokauran-19-oate (4), ent-19methoxy-19-oxokauran-17-oic acid (7), methyl ent-16 $\beta$ hydroxy-17-norkauran-19-oate (8) and methyl ent-16oxo-17-norkauran-19-oate (9), from the usual PDC oxidation of methyl ent-17-hydroxykauran-19-oate (6). The nomenclature and numbering of ent-kaurane derivatives obtained in this work follow the IUPAC recomendations. ${ }^{13}$

\section{Results and Discussion}

Kaurenoic acid (1), isolated from aerial parts of Wedelia paludosa D.C., ${ }^{4,5}$ was esterified with diazomethane to the corresponding methyl ester $\mathbf{2}$, which was subjected to two different pathways of chemical transformation (Scheme 1). 


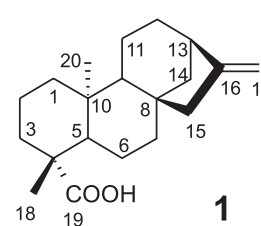

1

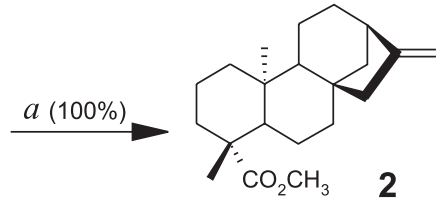

2
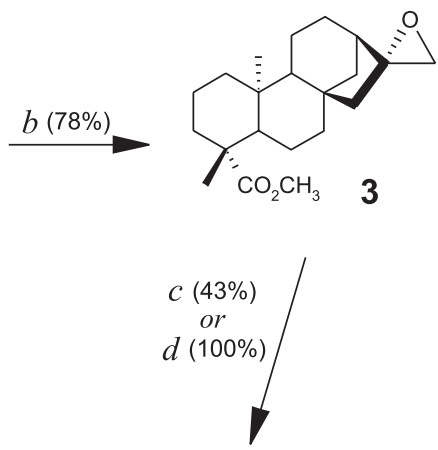<smiles>CC(=O)C1(C)CCCC2C3CCC4(CO)CC3CCC2C41</smiles>

6

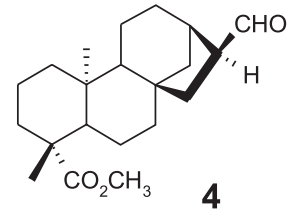

4

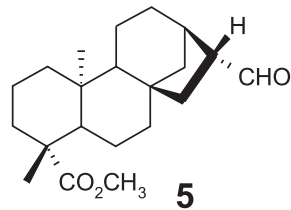

$(1: 1)$ $\mathrm{CO}_{2} \mathrm{CH}_{3} \quad 5$

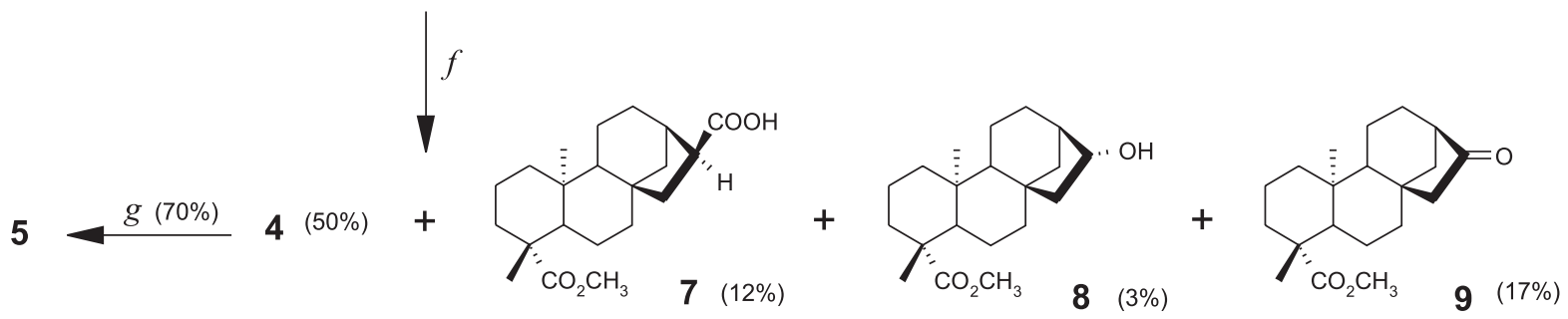

Scheme 1. Reagents and conditions: a) $\mathrm{CH}_{2} \mathrm{~N}_{2}, \mathrm{Et}_{2} \mathrm{O} ;$ b) MCPBA, $\mathrm{NaHCO}_{3}, \mathrm{CH}_{2} \mathrm{Cl}_{2}, 30 \mathrm{~min} ;$ c) $\mathrm{InCl}_{3}, \mathrm{THF}, 1 \mathrm{~h} ;$ d) $\mathrm{BF}_{3} \cdot \mathrm{Et}_{2} \mathrm{O}, \mathrm{C}_{6} \mathrm{H}_{6}, 30 \mathrm{~min} ; e$ ) 1$) \mathrm{NaBH}_{4}$, $\left.\left.\left.\mathrm{BF}_{3} \cdot \mathrm{Et}_{2} \mathrm{O}, \mathrm{THF}, 1 \mathrm{~h} ; 2\right) \mathrm{NaOH}, \mathrm{H}_{2} \mathrm{O}_{2}, 50^{\circ} \mathrm{C}, 2 \mathrm{~h} ; f\right) \mathrm{PDC}, \mathrm{CH}_{2} \mathrm{Cl}_{2}, 7.5 \mathrm{~h} ; \mathrm{g}\right) \mathrm{HCl}, \mathrm{HOAc}, 80^{\circ} \mathrm{C}, 48 \mathrm{~h}$.

The first one was the epoxidation of $\mathbf{2}$ with MCPBA taking place stereoselectively at the more accesible side of the double bond, to yield exclusively the ent-16ß,17epoxide 3, what was confirmed by X-ray crystallography. ${ }^{14}$ Further rearrangement of $\mathbf{3}$ employing Lewis acids such as $\mathrm{InCl}_{3}$ or $\mathrm{BF}_{3}$ afforded a 1:1 mixture of epimer aldehydes $\mathbf{4}$ and $\mathbf{5}$, in moderate to quantitative yields ( $43 \%$ and $100 \%$, respectively), that could not be separated by column chromatography. A mixture of products is usually obtained from rearrangement of epoxides to carbonyl compounds, due to lack of regioselectivity in the ring opening step. ${ }^{15}$

Moreover, methyl ester 2 was subjected to hydroboration reaction with $\mathrm{NaBH}_{4}$ and $\mathrm{BF}_{3} \cdot \mathrm{Et}_{2} \mathrm{O}$, followed by $\mathrm{NaOH}$ and $\mathrm{H}_{2} \mathrm{O}_{2}$ oxidation, giving exclusively the hydroxymethyl group at the ent- $\alpha$ side of the derivative 6. These results, affording stereoselectively the alcohol 6 with an ent-16 $\alpha$ configuration, are in agreement with literature data ${ }^{16}$ and are justified by the regio- and stereoselectivity of the hydroboration-oxidation reaction, with a syn-addition taking place at the less hindered face of the double bond. Next, the PDC oxidation of $\mathbf{6}$ yielded the aldehyde $\mathbf{4}$ as the major product, together with the ent-kaurane $\mathbf{7}$ and ent-norkauranes 8 and $\mathbf{9}$ as minor products. The isomerization of $\mathbf{4}$ into its more stable epimer 5 was satisfactoriously performed by hydrochloric and acetic acids condition.

At the best of our knowledge, this is the first report of the kaurane and norkaurane derivatives 4, 7, 8 and 9 by the oxidation of methyl ent-17-hydroxykauran-19-oate (6) under PDC conditions. These products may be considered as subsequent oxidized compounds from alcohol $\mathbf{6}$. The initial oxidation of $\mathbf{6}$ afforded the expected aldehyde $\mathbf{4}$, which in the presence of the chromate underwent further oxidation to the acid 7. This acid can be considered the precursor of the norkauranes $\mathbf{8}$ and $\mathbf{9}$ according to the mechanism proposed in Scheme 2. As seen in this scheme, the key step of this mechanism is pointed to be the nucleofilic addition between $\mathrm{HCrO}_{3}^{-}(1 \mathrm{~mol})$ and the acid 7, followed by intra- $\mathrm{SN}_{2}$ rearrangement of this intermediate and finally a decarboxylation-oxidation step, respectively. So, it is possible to explain the synthesis of the norkaurane alcohol $\mathbf{8}$, bearing an ent- $\beta$ configuration at $\mathrm{C}-16$, in opposite to the other kaurane derivatives 4,6 and 7 , that stand an ent-16 $\alpha$ configuration.

All products were characterized by mass, NMR and IR spectroscopies. Known compounds 1, 2, 3, 6, 7 and 9 were identified by comparison of their spectral properties (MS, ${ }^{1} \mathrm{H}$ NMR and, except for 3, ${ }^{13} \mathrm{C}$ NMR) with those reported in literature. ${ }^{16-20}$ Compounds $\mathbf{4 , 5}$ and $\mathbf{8}$, along 

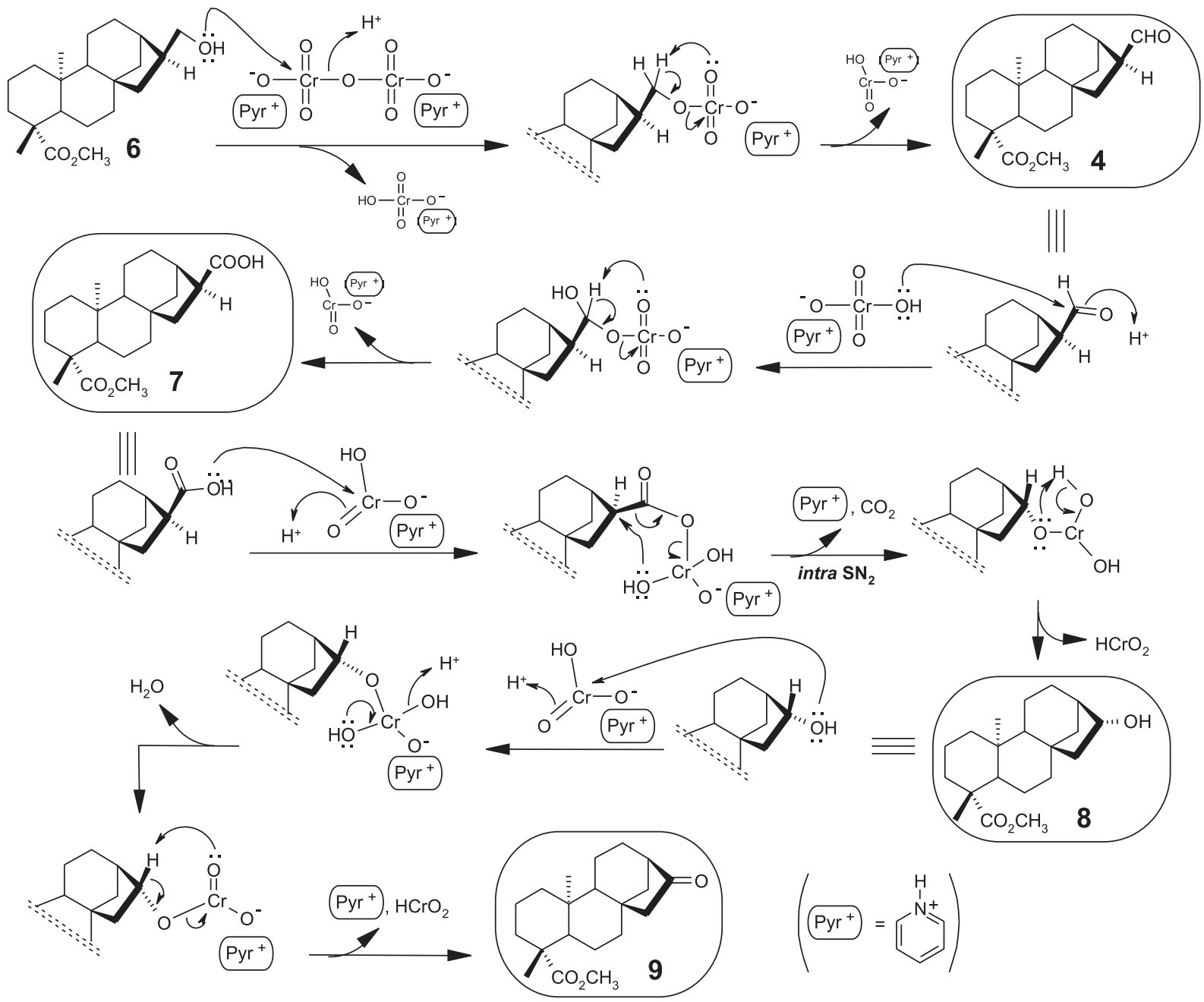

Scheme 2. Mechanism proposed for the synthesis of ent-kaurane and ent-norkaurane derivatives $\mathbf{4}, \mathbf{7}, \mathbf{8}$ and $\mathbf{9}$, from the oxidation of ent-kaurane alcohol 6 under PDC conditions.

with ${ }^{13} \mathrm{C}$ NMR data for compound $\mathbf{3}$, are reported here for the first time as far as the authors know.

Structures of compounds $\mathbf{4}$ and $\mathbf{5}$ were established on the basis of their IR, NMR $\left({ }^{1} \mathrm{H}\right.$ NMR, ${ }^{13} \mathrm{C}$ NMR $)$ and mass spectral data. FAB-HRMS data indicated molecular masses for 4 (333.2417) and for 5 (333.2428), both in agreement with the molecular formula $\mathrm{C}_{21} \mathrm{H}_{32} \mathrm{O}_{3}$ (calculated = 333.2430). Aldehyde functions of $\mathbf{4}$ and $\mathbf{5}$ were evident in their IR spectra, with a $\mathrm{C}-\mathrm{H}$ stretching band of - $\mathrm{CHO}$ group at $2701 \mathrm{~cm}^{-1}$ and in their ${ }^{1} \mathrm{H}$ NMR spectra, by characteristic signals at $\delta 9.89$ and $\delta 9.65$ (1H each), respectively (Table 1 ). The ent- $\alpha$ and ent- $\beta$ orientations of aldehydes $\mathbf{4}$ and $\mathbf{5}$, respectively, were deduced from the chemical shifts and multiplicity of $\mathrm{H}-17$, which was deshielded as a singlet at $\delta 9.89$ (4) or shielded as $\mathrm{a}^{2} J 1.8$ doublet at $\delta 9.65$ (5) by the carbonyl group, according to literature data. ${ }^{21}$ The shielded chemical shift of C-12 observed for 4 ( $\delta$ 27.0), in comparison to that for $\mathbf{5}(\delta 30.9)$, indeed ensure this assignement (Table 2).
The norkaurane pattern of methyl esters 8 and 9 was confirmed by both ${ }^{13} \mathrm{C}$ NMR (20 signals each compound) and FAB-HRMS $\left(\mathrm{C}_{20} \mathrm{H}_{32} \mathrm{O}_{3}\right.$ and $\mathrm{C}_{20} \mathrm{H}_{30} \mathrm{O}_{3}$, respectively) methods. There is a close similarity between ${ }^{1} \mathrm{H}$ NMR and ${ }^{13} \mathrm{C}$ NMR (Tables 1 and 2) data of these compounds, the differences being those related to the alcohol (8) and ketone (9) functions at C-16. The location of the $-\mathrm{OH}$ group at $\mathrm{C}-16$ in structure 8 was confirmed by the correlations in the COSY spectrum between H-16 ( $\delta$ 4.14, d, $J$ 6.0), H-15 $\alpha$ $(\delta 1.90, \mathrm{~m})$ and $\mathrm{H}-15 \beta(\delta 1.20, \mathrm{~m})$, in addition to the helpfull HMQC spectrum data. The ent- $\beta$ configuration of the $-\mathrm{OH}$ group at $\mathrm{C}-16$ position was assigned in terms of gauche interactions, by comparison of its C-12 $(\delta$ 28.7) and C-14 ( $\delta$ 36.1) chemical shifts with those ( $\delta 29.0$ and $\delta 38.5$, respectively) from the epoxide 3 (Table 2). This assignement is also corroborated by the multiplicity observed for the H-16 signal (Table 1), since the doublet format is understandable if there is a 
Table 1. ${ }^{1} \mathrm{H}$ NMR data $\delta / \mathrm{ppm} ;(\mathrm{J} / \mathrm{Hz})$ for compounds 1-9

\begin{tabular}{lccccccccc}
\hline $\mathrm{H}$ & $\mathbf{1}$ & $\mathbf{2}$ & $\mathbf{3}$ & $\mathbf{4}$ & $\mathbf{5}$ & $\mathbf{6}$ & $\mathbf{7}$ & $\mathbf{8}$ & $\mathbf{9}$ \\
\hline 13 & $2.64 \mathrm{bs}$ & $2.64 \mathrm{bs}$ & $2.30-2.00 \mathrm{~m}$ & $2.72 \mathrm{bs}$ & $2.54 \mathrm{~m}$ & $2.13 \mathrm{bs}$ & $2.57 \mathrm{bs}$ & $2.07 \mathrm{bs}$ & $2.40 \mathrm{bs}$ \\
$15 \mathrm{a} / \mathrm{b}$ & $2.05 \mathrm{~m}$ & $2.05 \mathrm{~m}$ & $2.00-1.50 \mathrm{~m}$ & $2.00-1.50 \mathrm{~m}$ & $2.00-1.50 \mathrm{~m}$ & $2.20-1.50 \mathrm{~m}$ & $2.20-1.50 \mathrm{~m}$ & $1.90 \mathrm{~m} / 1.20 \mathrm{~m}$ & $2.50-2.00 \mathrm{~m}$ \\
16 & & & & $2.80 \mathrm{dd}(6.2 / 12.1)$ & $2.54 \mathrm{~m}$ & $2.28 \mathrm{~m}$ & $2.95 \mathrm{q}(6.1)$ & $4.14 \mathrm{~d}(6.0)$ & \\
$17 \mathrm{a}$ & $4.79 \mathrm{bs}$ & $4.79 \mathrm{bs}$ & $2.88 \mathrm{~d}(4.8)$ & $9.89 \mathrm{~s}$ & $9.65 \mathrm{~d}(1.8)$ & $3.70 \mathrm{~d}(6.9)$ & & & \\
$17 \mathrm{~b}$ & $4.73 \mathrm{bs}$ & $4.74 \mathrm{bs}$ & $2.80 \mathrm{~d}(4.8)$ & & & & & & \\
18 & $1.24 \mathrm{~s}$ & $1.17 \mathrm{~s}$ & $1.17 \mathrm{~s}$ & $1.17 \mathrm{~s}$ & $1.17 \mathrm{~s}$ & $1.16 \mathrm{~s}$ & $1.17 \mathrm{~s}$ & $0.82 \mathrm{~s}$ & $0.90 \mathrm{~s}$ \\
20 & $0.95 \mathrm{~s}$ & $0.83 \mathrm{~s}$ & $0.84 \mathrm{~s}$ & $0.80 \mathrm{~s}$ & $0.81 \mathrm{~s}$ & $0.81 \mathrm{~s}$ & $0.81 \mathrm{~s}$ & $3.64 \mathrm{~s}$ & $3.66 \mathrm{~s}$ \\
21 & & $3.64 \mathrm{~s}$ & $3.65 \mathrm{~s}$ & $3.64 \mathrm{~s}$ & $3.64 \mathrm{~s}$ & $3.64 \mathrm{~s}$ & $3.64 \mathrm{~s}$ & \\
\hline
\end{tabular}

Table 2. ${ }^{13} \mathrm{C}$ NMR $(\delta / \mathrm{ppm})$ data for compounds 1-9

\begin{tabular}{cccccccccc}
\hline $\mathbf{C}$ & $\mathbf{1}$ & $\mathbf{2}$ & $\mathbf{3}$ & $\mathbf{4}$ & $\mathbf{5}$ & $\mathbf{6}$ & $\mathbf{7}$ & $\mathbf{8}$ & $\mathbf{9}$ \\
\hline 1 & 40.7 & 40.8 & 40.8 & 40.7 & 40.8 & 40.8 & 40.6 & 40.8 & 40.7 \\
2 & 19.1 & 19.1 & 19.6 & 19.1 & 19.1 & 19.2 & 19.1 & 19.1 & 19.0 \\
3 & 37.7 & 38.1 & 38.1 & 38.1 & 38.0 & 38.1 & 38.0 & 38.1 & 37.3 \\
4 & 43.2 & 43.8 & 43.8 & 43.8 & 43.8 & 43.7 & 43.7 & 43.8 & 42.4 \\
5 & 57.1 & 57.1 & 57.0 & 57.0 & 56.9 & 57.0 & 56.9 & 57.4 & 56.8 \\
6 & 21.8 & 21.9 & 21.9 & 22.2 & 22.4 & 22.3 & 22.1 & 22.4 & 20.8 \\
7 & 41.3 & 41.3 & 41.2 & 39.6 & 37.7 & 42.1 & 41.5 & 41.4 & 41.0 \\
8 & 44.2 & 44.2 & 45.4 & 44.5 & 45.1 & 44.2 & 44.3 & 45.6 & 43.8 \\
9 & 55.1 & 55.1 & 55.0 & 55.7 & 55.2 & 56.4 & 56.1 & 54.8 & 54.0 \\
10 & 39.7 & 39.4 & 39.4 & 39.4 & 39.4 & 39.5 & 39.3 & 39.4 & 39.5 \\
11 & 18.4 & 18.4 & 19.1 & 18.4 & 18.8 & 19.2 & 18.2 & 19.1 & 18.7 \\
12 & 33.1 & 33.1 & 29.0 & 27.0 & 30.9 & 26.0 & 27.3 & 28.7 & 29.5 \\
13 & 43.8 & 43.8 & 42.5 & 53.4 & 53.6 & 37.0 & 45.3 & 45.6 & 47.7 \\
14 & 39.7 & 39.7 & 38.5 & 40.7 & 40.1 & 40.4 & 41.5 & 36.1 & 37.9 \\
15 & 48.9 & 48.9 & 48.7 & 41.6 & 41.0 & 43.8 & 40.6 & 53.0 & 54.9 \\
16 & 155.9 & 155.9 & 66.3 & 38.9 & 37.7 & 43.3 & 39.5 & 75.7 & 222.5 \\
17 & 103.0 & 102.9 & 50.4 & 204.4 & 203.7 & 64.2 & 180.3 & 28.7 & 28.7 \\
18 & 29.0 & 28.7 & 28.7 & 28.8 & 28.7 & 28.7 & 178.1 & 28.7 \\
19 & 184.8 & 178.1 & 178.1 & 178.1 & 178.0 & 178.2 & 17.1 & 178.1 & 177.9 \\
20 & 15.6 & 15.4 & 15.6 & 15.5 & 15.3 & 15.4 & 15.3 & 15.6 & 15.9 \\
21 & & 51.1 & 51.2 & 51.2 & 51.1 & 51.1 & 51.1 & 51.1 & 51.2 \\
\hline
\end{tabular}

$90^{\circ}$ diedral angle of $\mathrm{H}-16$ simultaneosly with $\mathrm{H}-13$ and $\mathrm{H}-15 \alpha$, that ocurrs just when $\mathrm{H}-16$ is at ent- $\alpha$ configuration.

\section{Conclusions}

This work reports the synthesis of new oxidized entkaurane (4 and $\mathbf{5})$ and ent-norkaurane (8) derivatives starting from kaurenoic acid (1). In addition, we describe here, for the first time, the synthesis of compounds $\mathbf{4}, \mathbf{7}, \mathbf{8}$ and 9 by the oxidation of methyl ent-17-hydroxykauran19-oate (6) under PDC conditions.

\section{Experimental}

\section{General experimental procedures}

Melting points were taken with a Microquímica apparatus APF-301 and were uncorrected. Optical rotations were measured with a Perkin-Elmer 241 digital polarimeter. IR spectra were obtained on a Shimadzu IR-400 and Nicolet Impact 410 spectrophotometer. NMR spectra were recorded at $200 \mathrm{MHz}$ for ${ }^{1} \mathrm{H}$ and $50 \mathrm{MHz}$ for ${ }^{13} \mathrm{C}$ in deuterochloroform, added of TMS as internal reference, on a Bruker AC 200. The assignments of carbon signals were made by comparison with literature data and by means of $2 \mathrm{D}$ NMR ${ }^{1} \mathrm{H}$ and ${ }^{13} \mathrm{C}$ single bond correlation studies, on a Bruker Advance DRX400 (400 $\mathrm{MHz}$ for ${ }^{1} \mathrm{H}$ and $100 \mathrm{MHz}$ for ${ }^{13} \mathrm{C}$ in deuterochloroform). Chemical shift values are expressed in ppm and coupling constants $(J)$ in Hz. Column chromatography (CC) and flash column chromatography (FCC) were performed on silica gel Merck 60 (0.063-0.200 and 0.040-0.063 mm, respectively). HRMS were run in a VG TS-250 spectrometer working at $70 \mathrm{eV}$. TLC were carried out on silica gel Merck $60 \mathrm{~F}_{254}(0.25 \mathrm{~mm}$ thick). Solvents and reagents were purified by standard procedures as necessary. 
ent-Kaur-16-en-19-oic acid (kaurenoic acid) (1)

Obtained from Wedelia paludosa ethanol extract, as described previously. ${ }^{5}{ }^{1} \mathrm{H}$ NMR data, Table $1 .{ }^{13} \mathrm{C}$ NMR data, Table 2.

\section{Methyl ent-kaur-16-en-19-oate (2)}

Obtained from kaurenoic acid (1) (500 mg) by usual procedure with an ethereal solution $(100 \mathrm{~mL})$ of diazomethane giving the ester $2(527 \mathrm{mg})$ in quantitative yield. mp $80-82^{\circ} \mathrm{C}\left(\right.$ Lit. $\left.^{22} 72-75^{\circ} \mathrm{C}\right) ;[\alpha]_{\mathrm{D}}^{25}-82.8^{\circ}, \mathrm{CH}_{2} \mathrm{Cl}_{2}$, c 1.08 (Lit. $^{22}-91.9^{\circ}, \mathrm{CHCl}_{3}, c$ 7.93). IR (film) $\mathrm{v}_{\max } / \mathrm{cm}^{-1}$ : 3064, 1724, 1656. ${ }^{1} \mathrm{H}$ NMR data, Table $1 .{ }^{13} \mathrm{C}$ NMR data, Table 2.

\section{Methyl ent-kauran-16 $\beta, 17$-epoxy-19-oate (3)}

The methyl ester 2 (266 mg, $0.84 \mathrm{mmol}$ ) in dry $\mathrm{CH}_{2} \mathrm{Cl}_{2}$ $(15 \mathrm{~mL})$ was treated with MCPBA $(55 \%, 298 \mathrm{mg}, 0.96$ $\mathrm{mmol}$ ), and the mixture was stirred at room temperature, in the presence of $\mathrm{NaHCO}_{3}$ excess $(500 \mathrm{mg})$. After 30 minutes, the solution was washed with aq. satd. $\mathrm{Na}_{2} \mathrm{~S}_{2} \mathrm{O}_{3}$, water and brine, and dried $\left(\mathrm{Na}_{2} \mathrm{SO}_{4}\right)$. The organic solvent was evaporated and the product was purified by FCC on silica-gel, eluting with $n$-hexane-EtOAc $(95: 5)$ to give compound 3 (217 mg, $78 \%$ ), mp 129-131 ${ }^{\circ} \mathrm{C}$ (Lit. $^{18}$ colourless gum); $[\alpha]_{\mathrm{D}}^{25}-108.8^{\circ}, \mathrm{CHCl}_{3}, c 0.93$ (Lit. $^{18}-84^{\circ}$, $\mathrm{CHCl}_{3}, c$ 1.16). IR(film) $v_{\text {max }} / \mathrm{cm}^{-1}: 2986,1724 .{ }^{1} \mathrm{H}$ NMR data, Table $1 .{ }^{13} \mathrm{C}$ NMR data, Table 2. HRMS (FAB-POSI, M+1) Calc. 333.2430; Found 333.2407.

\section{Methyl ent-17-hydroxykauran-19-oate (6)}

The methyl ester 2 (302 mg, $0.96 \mathrm{mmol}$ ) in dry THF (20 $\mathrm{mL}$ ) was treated with diborane generated in situ by adding $\mathrm{NaBH}_{4}$ (364 mg, $9.62 \mathrm{mmol}$ ) followed by $\mathrm{BF}_{3} . \mathrm{Et}_{2} \mathrm{O}$ (dropwise, $1.2 \mathrm{~mL}, 9.55 \mathrm{mmol}$ ). After stirring for $2 \mathrm{~h}$ at room temperature under argon atmosphere, EtOH $(10 \mathrm{~mL})$, $5 \mathrm{~mol} \mathrm{~L}{ }^{-1} \mathrm{NaOH}(10 \mathrm{~mL})$ and $30 \% \mathrm{H}_{2} \mathrm{O}_{2}(5 \mathrm{~mL})$ were added at $0{ }^{\circ} \mathrm{C}$ and stirring continued for $1 \mathrm{~h}$, at $50^{\circ} \mathrm{C}$. The THF was evaporated and the residue was dissolved in EtOAc and washed with brine $(2 \times 100 \mathrm{~mL})$. The organic layer was dried $\left(\mathrm{Na}_{2} \mathrm{SO}_{4}\right)$ and concentrated under reduced pressure. The recovered product was purified by FCC eluting with $n$-hexane-EtOAc (9:1) to yield 6 (276 mg, 86\%). Gum (Lit. ${ }^{19}$ gum), $[\alpha]-68.1^{\circ}\left(\mathrm{CH}_{2} \mathrm{Cl}_{2}, c\right.$ 0.99). IR(film) $\mathrm{v}_{\max } / \mathrm{cm}^{-1}: 3379$, 2983, 1726, 1032. ${ }^{1} \mathrm{H}$ NMR data, Table $1 .{ }^{13} \mathrm{C}$ NMR data, Table 2. HRMS (FAB-POSI, M+1) Calc. 335.2586; Found 335.2588 .

\section{Procedures for preparation of compounds 4, 5, 7, 8 and 9}

\section{Step c, Scheme 1}

A solution of epoxide 3 (40 mg, $0.12 \mathrm{mmol})$ in THF
(3 mL) was added to a stirred suspension of $\mathrm{InCl}_{3}(16 \mathrm{mg}$, $0.07 \mathrm{mmol})$ in THF $(2 \mathrm{~mL})$ at room temperature and stirring was continued for $1 \mathrm{~h}$ for reaction completion (TLC). The mixture was concentrated under reduced pressure. The recovered product was purified by FCC eluting with $n$-hexane-EtOAc (93:7) to afford a 1:1 mixture of aldehydes $\mathbf{4}$ and $\mathbf{5}$ (17 $\mathrm{mg}, 43 \%$ ).

\section{Step $d$, Scheme 1}

The $\mathrm{BF}_{3} \cdot \mathrm{Et}_{2} \mathrm{O}$ complex $(10 \mu \mathrm{L}, 0.08 \mathrm{mmol})$ was added to a solution of epoxide 3 (41 $\mathrm{mg}, 0.12 \mathrm{mmol}$ ) in benzene $(5 \mathrm{~mL})$, and the system was stirred at room temperature under nitrogen by $30 \mathrm{~min}$. The mixture was concentrated under reduced pressure, affording a 1:1 mixture of aldehydes 4 and 5 (42 mg, 100\%).

\section{Step $f$, Scheme 1}

A solution of alcohol 6 (144 mg, $0.43 \mathrm{mmol}$ ) in $\mathrm{CH}_{2} \mathrm{Cl}_{2}$ (5 $\mathrm{mL}$ ) was added to a stirred suspension of PDC (280 mg, 0.74 mmol) and molecular sieves $(4 \AA)$ in $\mathrm{CH}_{2} \mathrm{Cl}_{2}(10 \mathrm{~mL})$. This system was stirred at room temperature under argon for $7.5 \mathrm{~h}$ till the reaction was complete (TLC). The mixture was concentrated under reduced pressure and the recovered product was purified by $\mathrm{CC}$ eluting with $\mathrm{CH}_{2} \mathrm{Cl}_{2}$ to give 4 (72 mg, $50 \%$ ) and 9 (23 mg, 17\%), and then eluted with $\mathrm{CH}_{2} \mathrm{Cl}_{2}-\mathrm{EtOAc}$ (96:4) to give 8 (4 mg, 3\%) and 7 (18 mg, 17\%).

\section{Step g, Scheme 1}

$\mathrm{HCl} 12 \mathrm{~mol} \mathrm{~L}^{-1}(0.5 \mathrm{~mL}, 6 \mathrm{mmol})$ was added to a solution of aldehyde 4 (23 mg, $0.07 \mathrm{mmol})$ in HOAc (3 $\mathrm{mL})$ and the solution was stirred under reflux $\left(80-100{ }^{\circ} \mathrm{C}\right)$ by $60 \mathrm{~h}$. The mixture was diluted with water $(100 \mathrm{~mL})$ and extracted with $\mathrm{CH}_{2} \mathrm{Cl}_{2}(100 \mathrm{~mL})$. The organic layer was dried $\left(\mathrm{Na}_{2} \mathrm{SO}_{4}\right)$ and concentrated under reduced pressure. The residue was purified by FCC eluting with $n$-hexane- $\mathrm{CH}_{2} \mathrm{Cl}_{2}(1: 1)$ to yield 5 (16 mg, 70\%).

\section{Methyl ent-17-oxokauran-19-oate (4)}

Colourless oil; $[\alpha]_{\mathrm{D}}^{25}-57.0^{\circ}, \mathrm{CDCl}_{3}, c$ 1.00; IR (film) $v_{\max } / \mathrm{cm}^{-1}: 2984,2701,1723 .{ }^{1} \mathrm{H}$ NMR data, Table $1 .{ }^{13} \mathrm{C}$ NMR data, Table 2. HRMS (FAB-POSI, M+1) Calc. 333.2430; Found 333.2417.

\section{Methyl ent-17-oxo-16 $\beta$-kauran-19-oate (5)}

Colourless oil; $[\alpha]_{\mathrm{D}}^{25}-105.6^{\circ}, \mathrm{CHCl}_{3}, c$ 0.80; IR (film) $v_{\max } / \mathrm{cm}^{-1}: 2943,2701,1724 .{ }^{1} \mathrm{H}$ NMR data, Table $1 .{ }^{13} \mathrm{C}$ NMR data, Table 2. HRMS (FAB-POSI, M+1) Calc. 333.2430; Found 333.2428.

ent-19-Methoxy-19-oxokauran-17-oic acid (7) $[\alpha]_{\mathrm{D}}^{25}-60.5^{\mathrm{o}}, \mathrm{CHCl}_{3}, c 1.10$ Lit. $^{20}-74.4^{\circ}, \mathrm{CHCl}_{3}, c$ 
0.86). IR (film) $v_{\max } / \mathrm{cm}^{-1}: 3400,1725,1699,1234 .{ }^{1} \mathrm{H}$ NMR data, Table $1 .{ }^{13} \mathrm{C}$ NMR data, Table 2. HRMS (FABPOSI, M+1) Calc. 349.2379; Found 349.2398.

Methyl ent-163-hydroxy-17-norkauran-19-oate (8) mp $126-128^{\circ} \mathrm{C} ;[\alpha]_{\mathrm{D}}^{25}-85.0^{\circ}, \mathrm{CHCl}_{3}, c 0.20$; IR (film) $V_{\max } / \mathrm{cm}^{-1}: 3400,1725,1234,1032 .{ }^{1} \mathrm{H}$ NMR data, Table 1. ${ }^{13} \mathrm{C}$ NMR data, Table 2. HRMS (FAB-POSI, M+1) Calc. 321.2430; Found 321.2466.

Methyl ent-16-oxo-17-norkauran-19-oate (9) $[\alpha]_{\mathrm{D}}^{25}-62.9^{\circ}, \mathrm{CHCl}_{3}, c 0.77\left(\right.$ Lit. $^{17}-55.2^{\circ}, \mathrm{CHCl}_{3}, c$ 0.77); IR (film) $v_{\max } / \mathrm{cm}^{-1}: 2986,1742,1724,1235,1011$. ${ }^{1} \mathrm{H}$ NMR data, Table $1 .{ }^{13} \mathrm{C}$ NMR data, Table 2. HRMS (FAB-POSI, M+1) Calc. 319.2273; Found 319.2245.

\section{Acknowledgments}

We are grateful to UESB, CAPES and CYTED (subprogram $\mathrm{X}$ ) for grants and financial support.

\section{Supplementary Information}

${ }^{1} \mathrm{H},{ }^{13} \mathrm{C}$ NMR and other data is avaliable free of charge at http://jbcs.sbq.org.br, as PDF file.

\section{References}

1. Ghisalberti, E. L.; Fitoterapia 1997, 68, 303.

2. Bruno, M.; Rosselli, S.; Pibiri, S.; Piozzi, F.; Bondi, M. L.; Simmonds, M. S. J.; Phytochemistry 2001, 58, 463.

3. Boeck, P.; Sá, M. M.; Souza, B. S.; Cercená, R.; Escalante, A. M.; Zachino, S. A.; Cechinel-Filho, V.; Yunes, R. A.; J. Braz. Chem. Soc. 2005, 16, 1360.

4. Batista, R.; Braga, F. C.; Oliveira, A. B.; Rev. Bras. Farmacogn. (Braz. J. Pharmacogn.) 2005, 15, 119.

5. Batista, R.; Chiari, E.; Oliveira, A. B.; Planta Med. 1999, 65, 283.
6. Zgoda-Pols, J. R.; Freyer, A. J.; Killmer, L. B.; Porter, J. R.; Fitoterapia 2002, 73, 434.

7. Yang, Y. L.; Chang, F. R.; Wu, C. C.; Wang, W. Y.; Wu, Y. C.; J. Nat. Prod. 2002, 65, 1462.

8. Block, L. C., Santos, A. R. S.; Souza, M. M.; Scheidt, C.; Yunes, R. A.; Santos, M. A.; Monache, F. D.; Cechinel-Filho, V.; J. Ethnopharmacol. 1998, 61, 85 .

9. Sartori, M. R. K.; Pretto, J. B.; Cruz, A. B.; Bresciani, L. F. V.; Yunes, R. A.; Sortino, M.; Zacchino, S. A.; Cechinel-Filho, V.; Pharmazie 2003, 58, 567.

10. Cunha, K. M. A.; Paiva, L. A.; Santos, F. A.; Gramosa, N. V.; Silveira, E. R.; Rao, V. S.; Phytother. Res. 2003, 17, 320.

11. Bresciani, L. F. V.; Yunes, R. A.; Burger, C.; Oliveira, L. E.; Bóf, K. L.; Cechinel-Filho, V.; Z. Naturforsch., C: J. Biosci. 2004, 59C, 229.

12. Costa-Lotufo, L.V.; Cunha, G. M. A.; Farias, P. A. M.; Viana, G. S. B.; Cunha, K. M. A.; Pessoa, C.; Moraes, M. O.; Silveira, E. R.; Gramosa, N. V.; Rao, V. S. N.; Toxicon 2002, 40, 1231.

13. Giles, P. M. Jr.; Pure Appl. Chem. 1999, 71, 587.

14. Batista, R.; García, P. A.; Castro, M. A.; Miguel del Corral, J. M.; Sanz, F.; Speziali, N. L.; Oliveira, A. B.; Acta Crystallogr., Sect. E: Struct. Rep. Online 2007, E63, o932.

15. Ranu, B. C.; Jana, U.; J. Org. Chem. 1998, 63, 8212.

16. Vieira, H. S.; Takahashi, J. A.; Boaventura, M. A. D.; Appl. Microbiol. Biotechnol. 2000, 53, 601.

17. Vieira, H. S.; Takahashi, J. A.; Oliveira, A. B.; Chiari, E.; Boaventura, M. A. D.; J. Braz. Chem. Soc. 2002, 13, 151.

18. Bohlman, F.; Adler, A.; Schuster, A.; Gupta, R. K.; King, R. M.; Robinson, H.; Phytochemistry 1981, 20, 1899.

19. Etse, J. T.; Gray, A. I.; Waterman, P. G.; J. Nat. Prod. 1987, 50, 979.

20. Fatope, M. O.; Audu, O.T.; J. Nat. Prod. 1996, 59, 301.

21. Bohlman, F.; Kramp, W.; Jakupovic, J.; Robinson, H.; King, R. M.; Phytochemistry 1982, 21, 399.

22. Costa, F. B.; Albuquerque, S.; Vichnewski, W.; Planta Med. 1996, 62, 557.
Received: August 27, 2006 Web Release Date: May 15, 2007 


\section{New Oxidized ent-Kaurane and ent-Norkaurane Derivatives from Kaurenoic Acid}

\section{Ronan Batista, ${ }^{*, a, c}$ Pablo A. García, ${ }^{b}$ Maria A. Castro, ${ }^{b}$ José M. Miguel del Corral, ${ }^{b}$ Arturo San Feliciano ${ }^{b}$ and Alaíde B. de Oliveira ${ }^{c}$}

${ }^{a}$ Departamento de Estudos Básicos e Instrumentais, Universidade Estadual do Sudoeste da Bahia, $B R$ 415, km 03, 45.700-000 Itapetinga-BA, Brazil

${ }^{b}$ Departamento de Química Farmacéutica, Facultad de Farmacia, Universidad de Salamanca, 37007 Salamanca, Spain

${ }^{c}$ Departamento de Produtos Farmacêuticos, Faculdade de Farmácia, Universidade Federal de Minas Gerais, Av. Antônio Carlos, 6.627, 31.270-901 Belo Horizonte-MG, Brazil

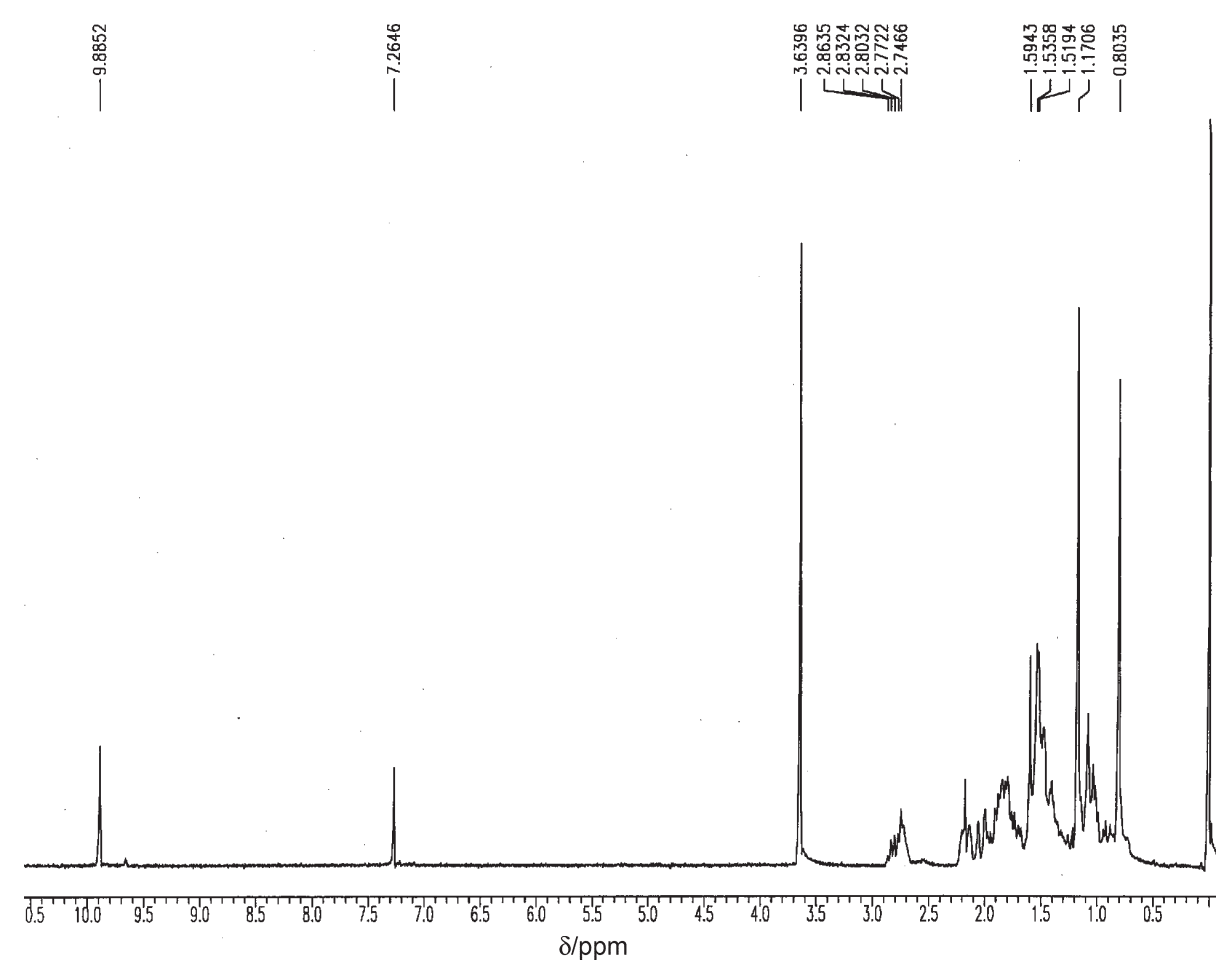

Figure S1. ${ }^{1} \mathrm{H}$ NMR for compound $4\left(200 \mathrm{MHz}, \mathrm{CDCl}_{3}\right)$. 

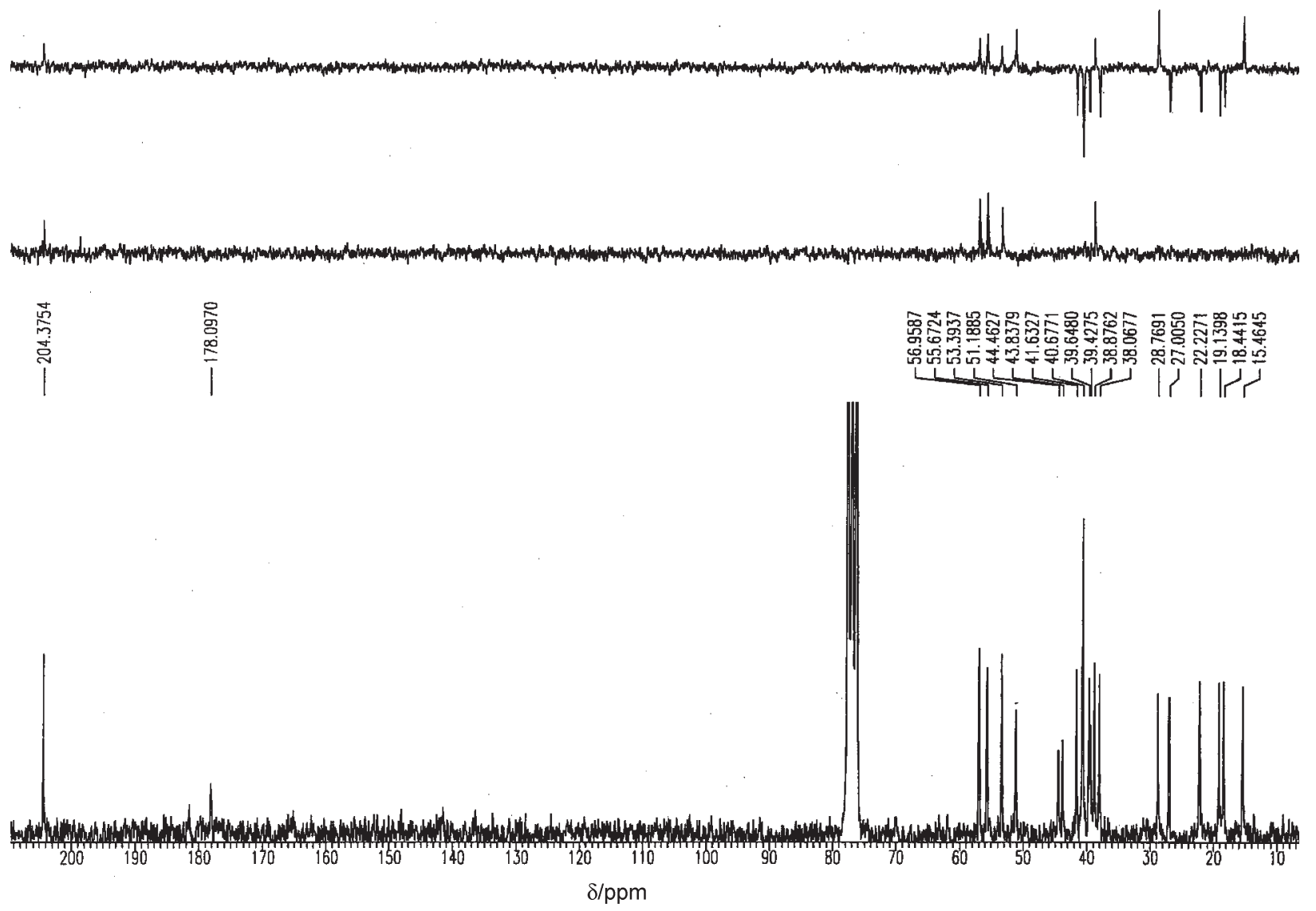

Figure S2. ${ }^{13} \mathrm{C}$ NMR, DEPT90 and DEPT135 for compound $4\left(50 \mathrm{MHz}, \mathrm{CDCl}_{3}\right)$.

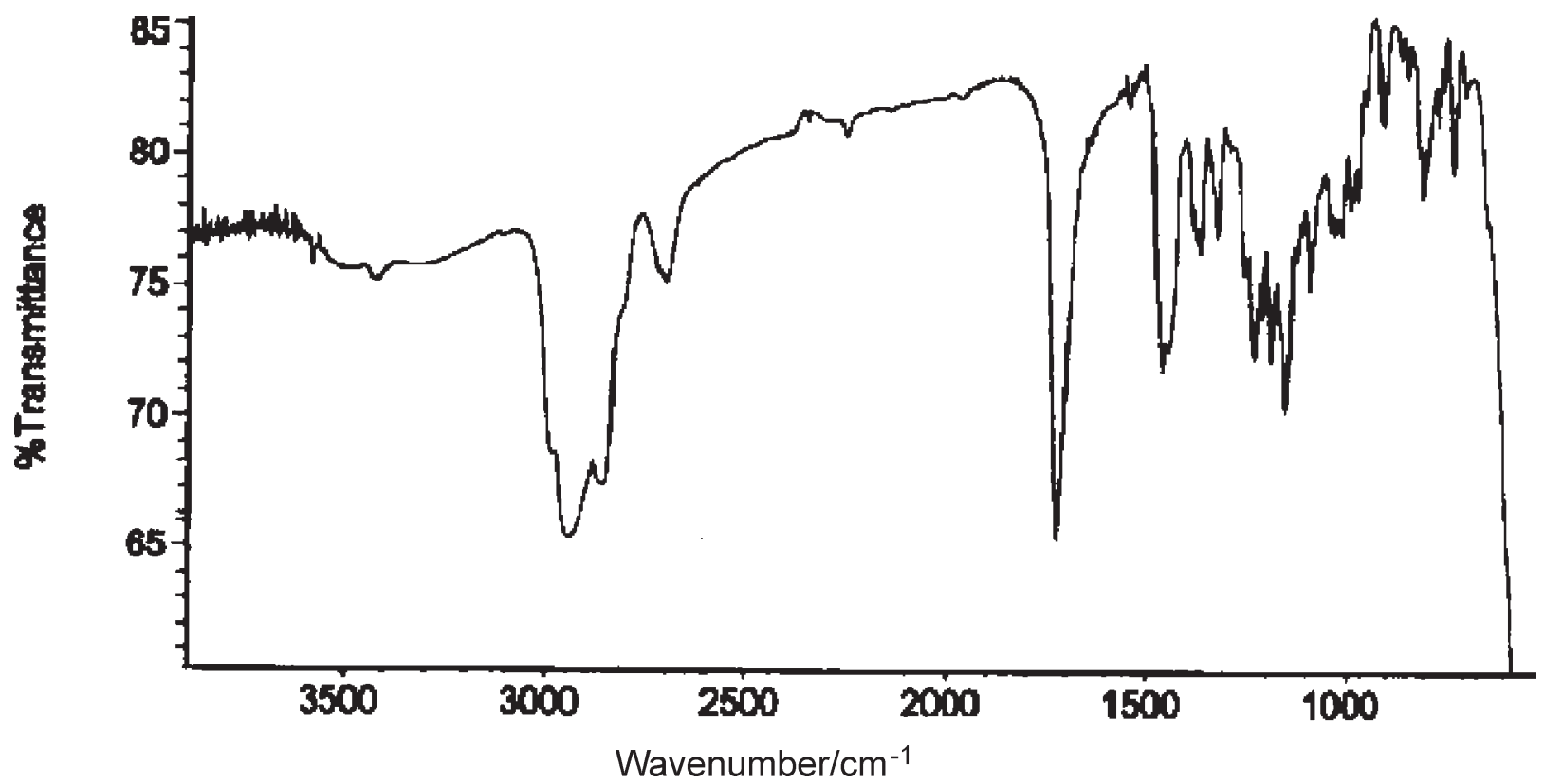

Figure S3. IR for compound 4. 


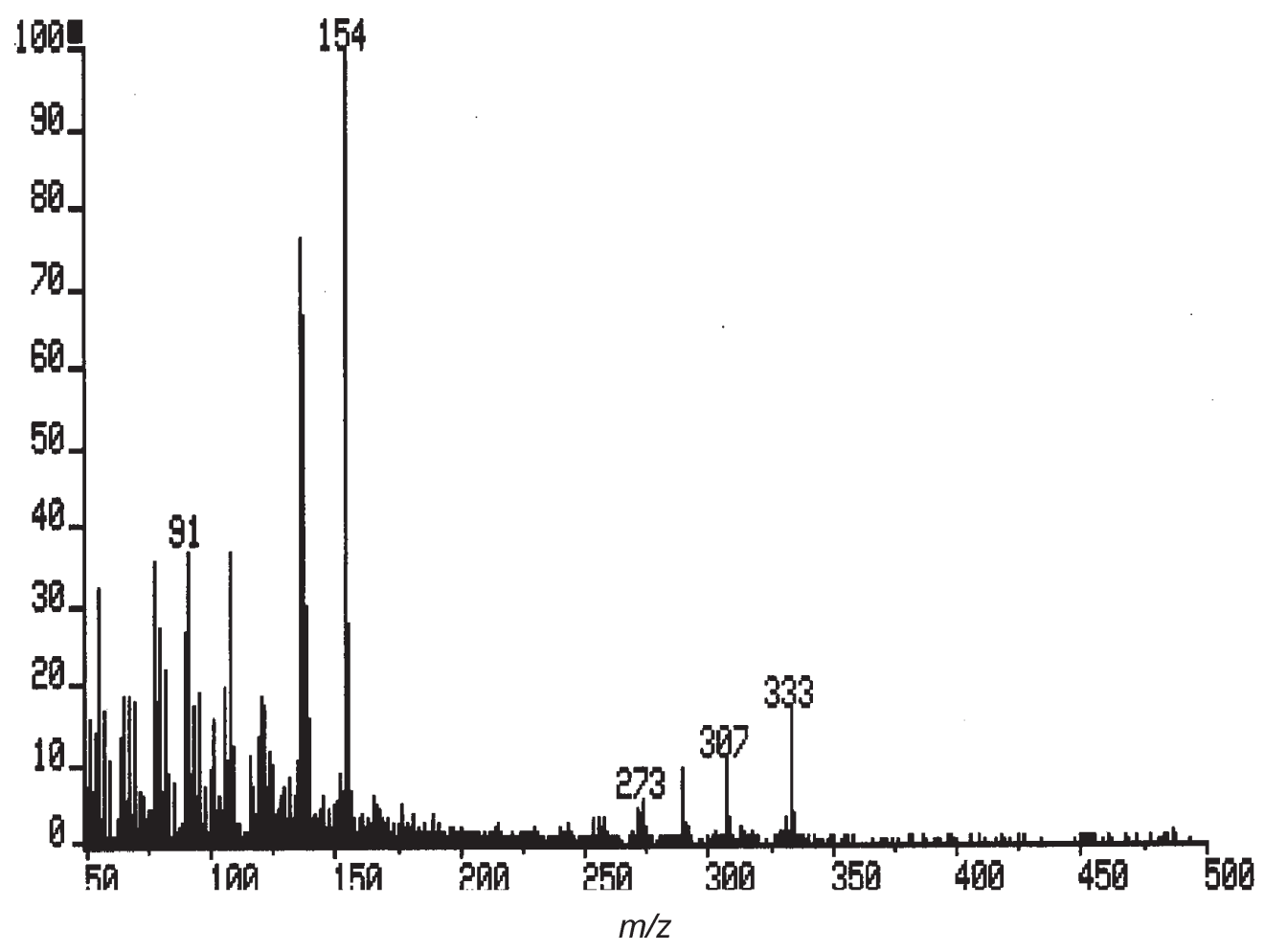

Figure S4. ESIMS for compound 4.

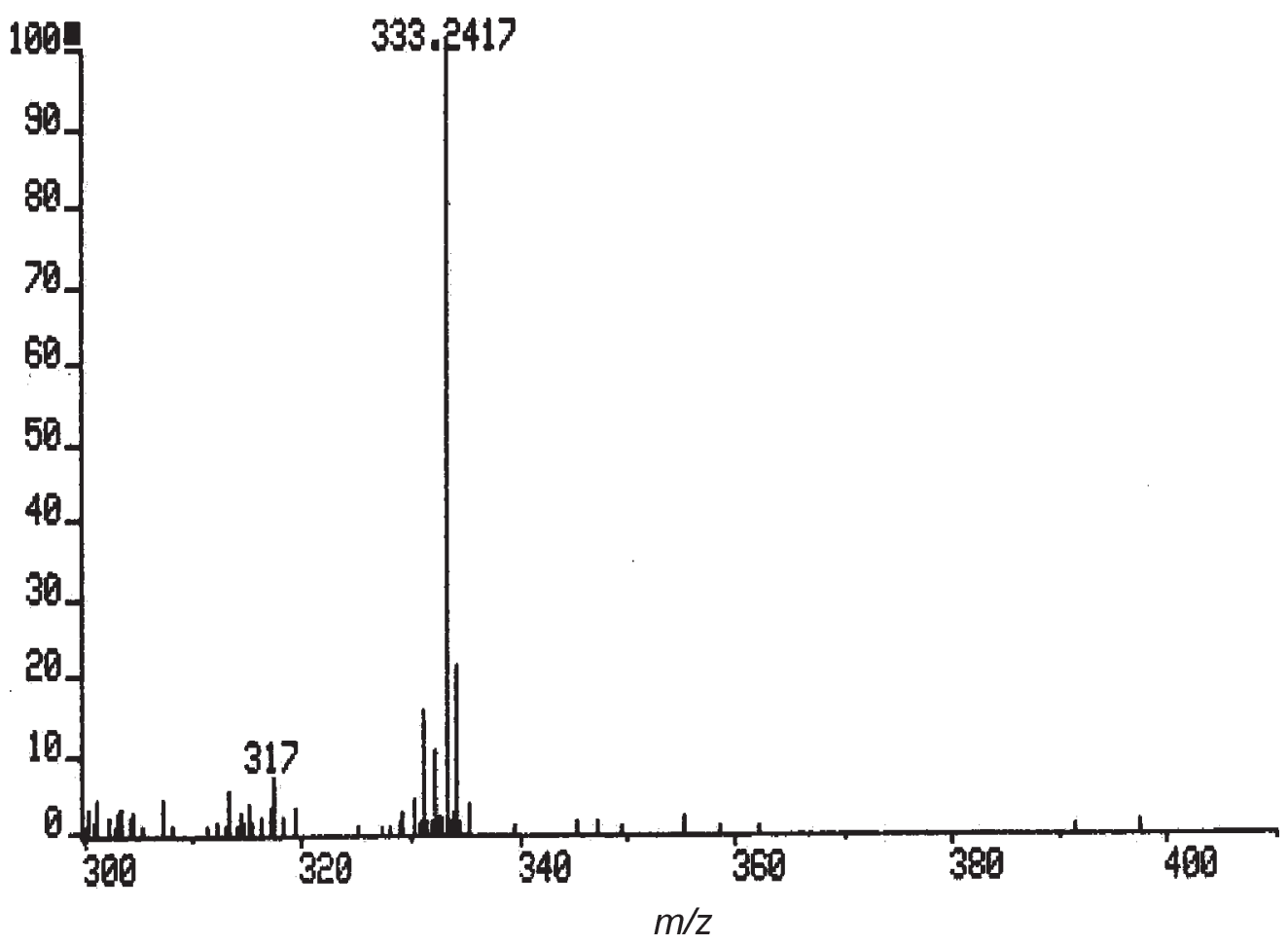

Figure S5. HRESIMS for compound 4. 


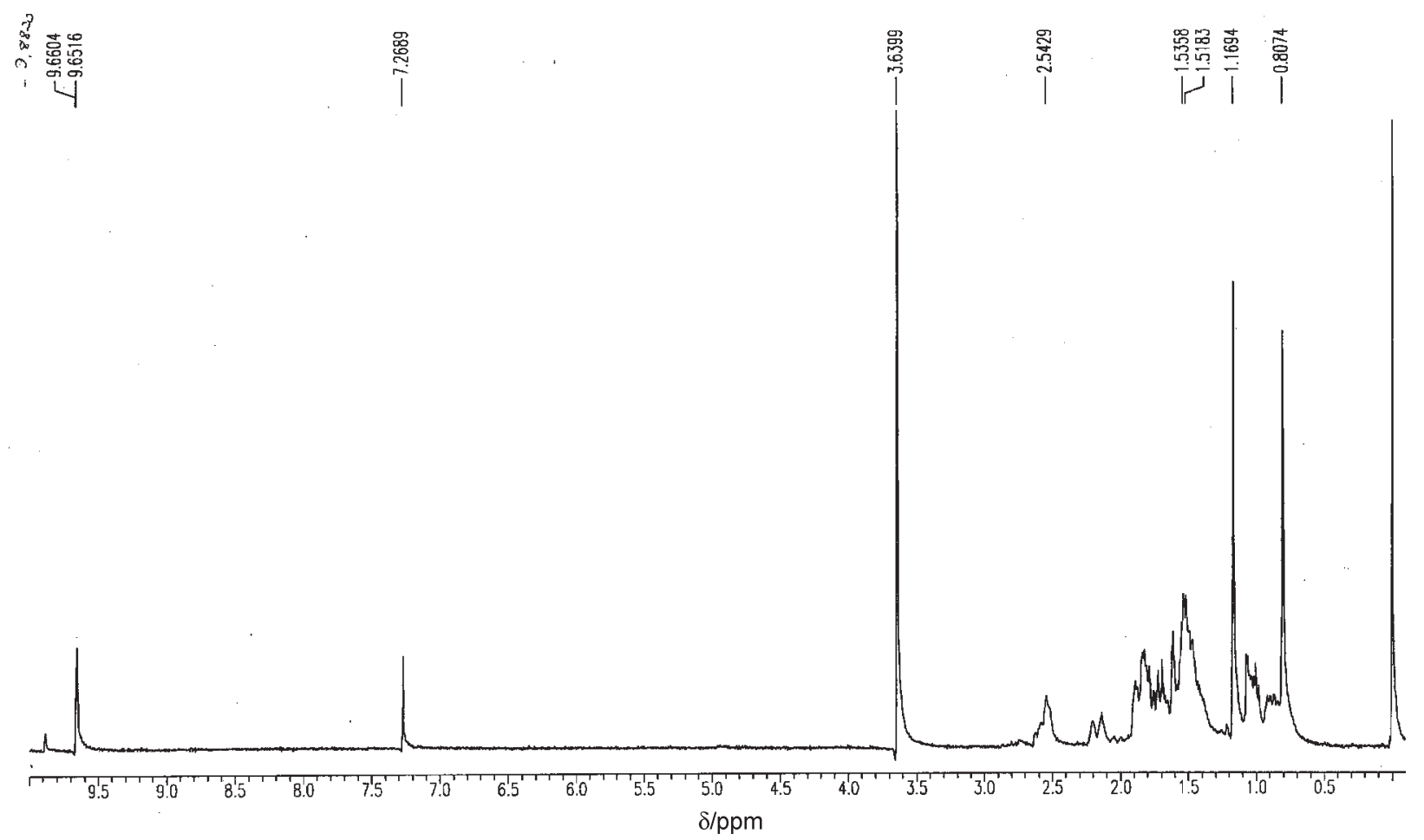

Figure S6. ${ }^{1} \mathrm{H}$ NMR for compound $5\left(200 \mathrm{MHz}, \mathrm{CDCl}_{3}\right)$.

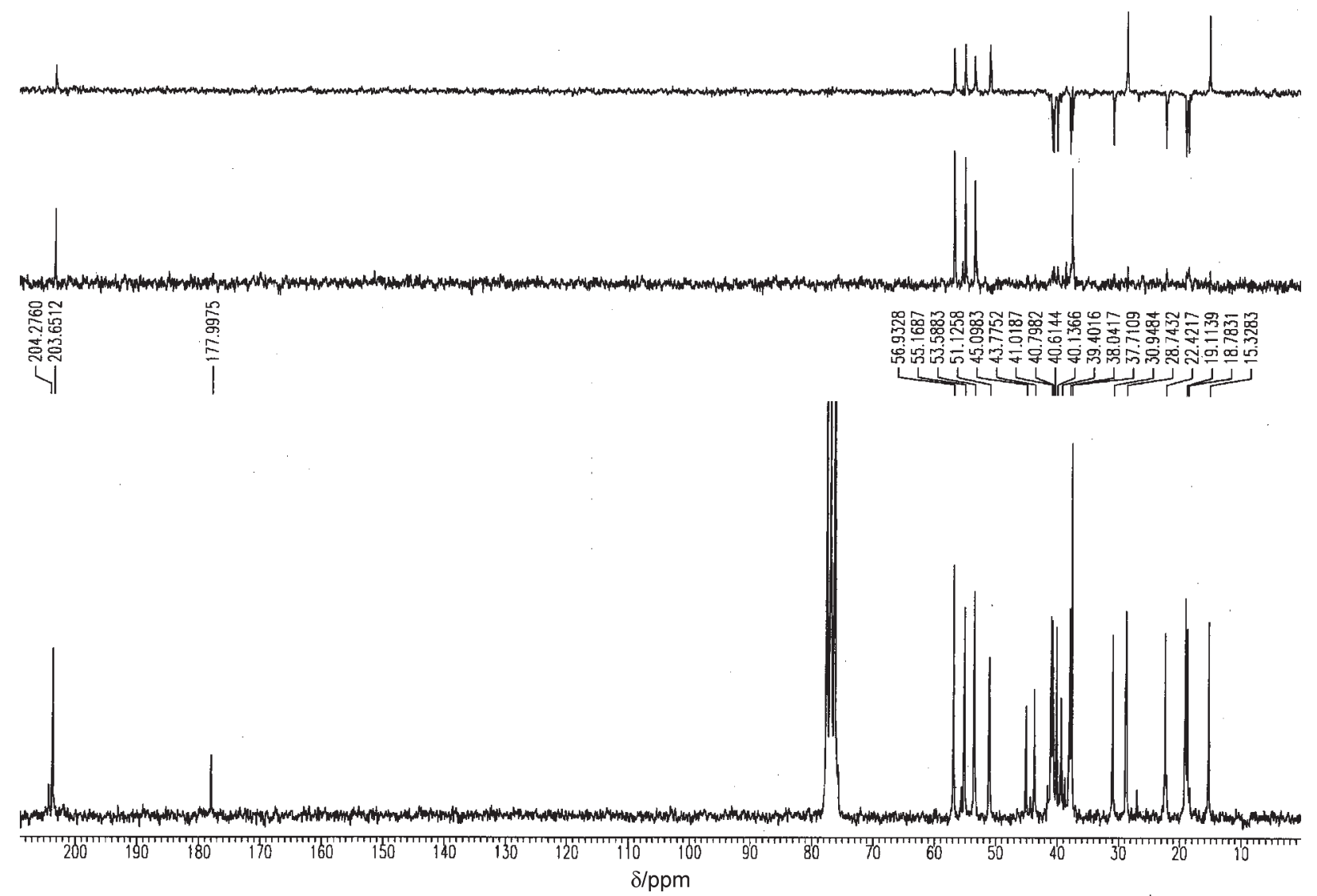

Figure S7. ${ }^{13} \mathrm{C}$ NMR, DEPT90 and DEPT135 for compound $5\left(50 \mathrm{MHz}, \mathrm{CDCl}_{3}\right)$. 


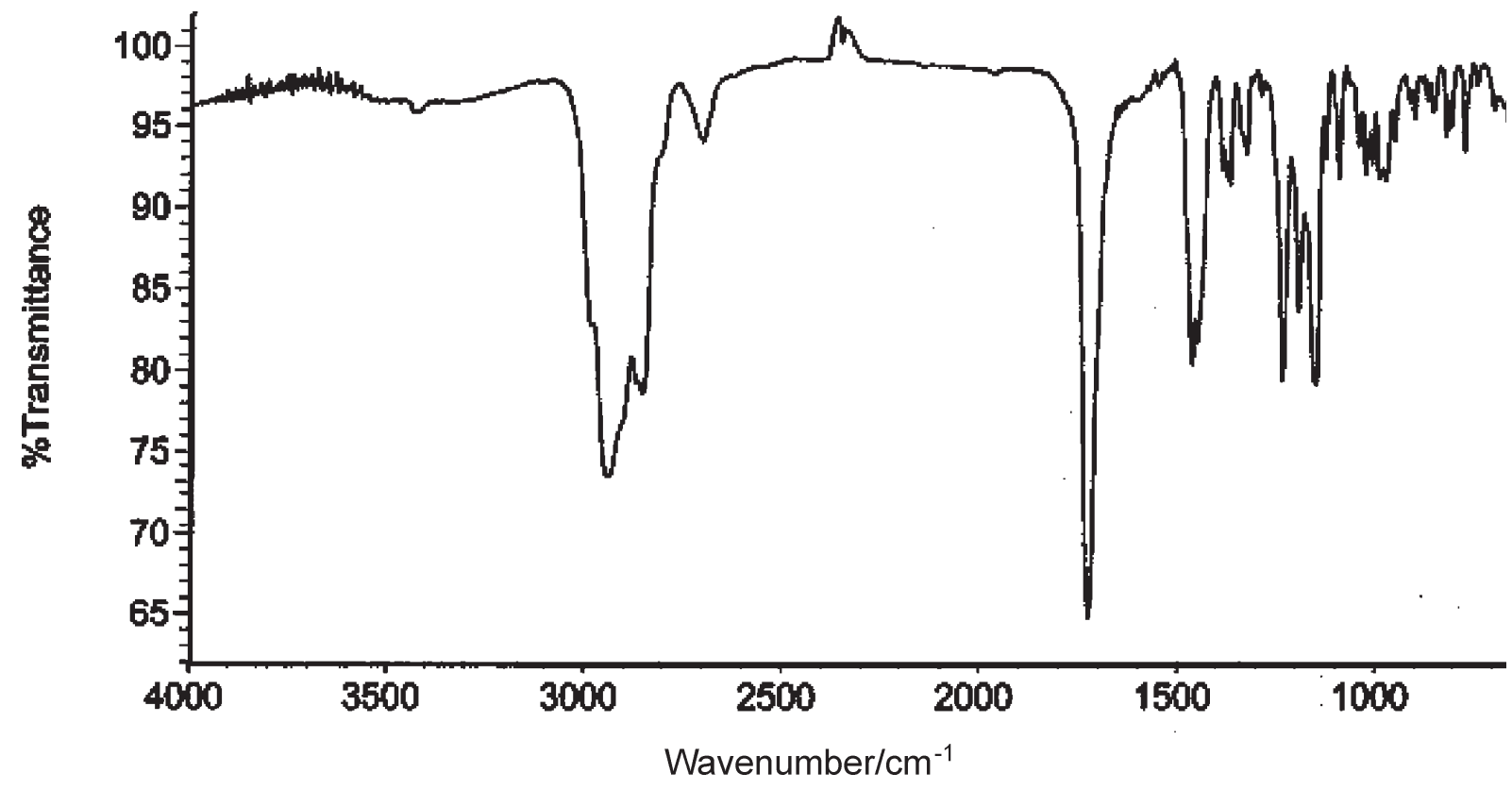

Figure S8. IR for compound 5.

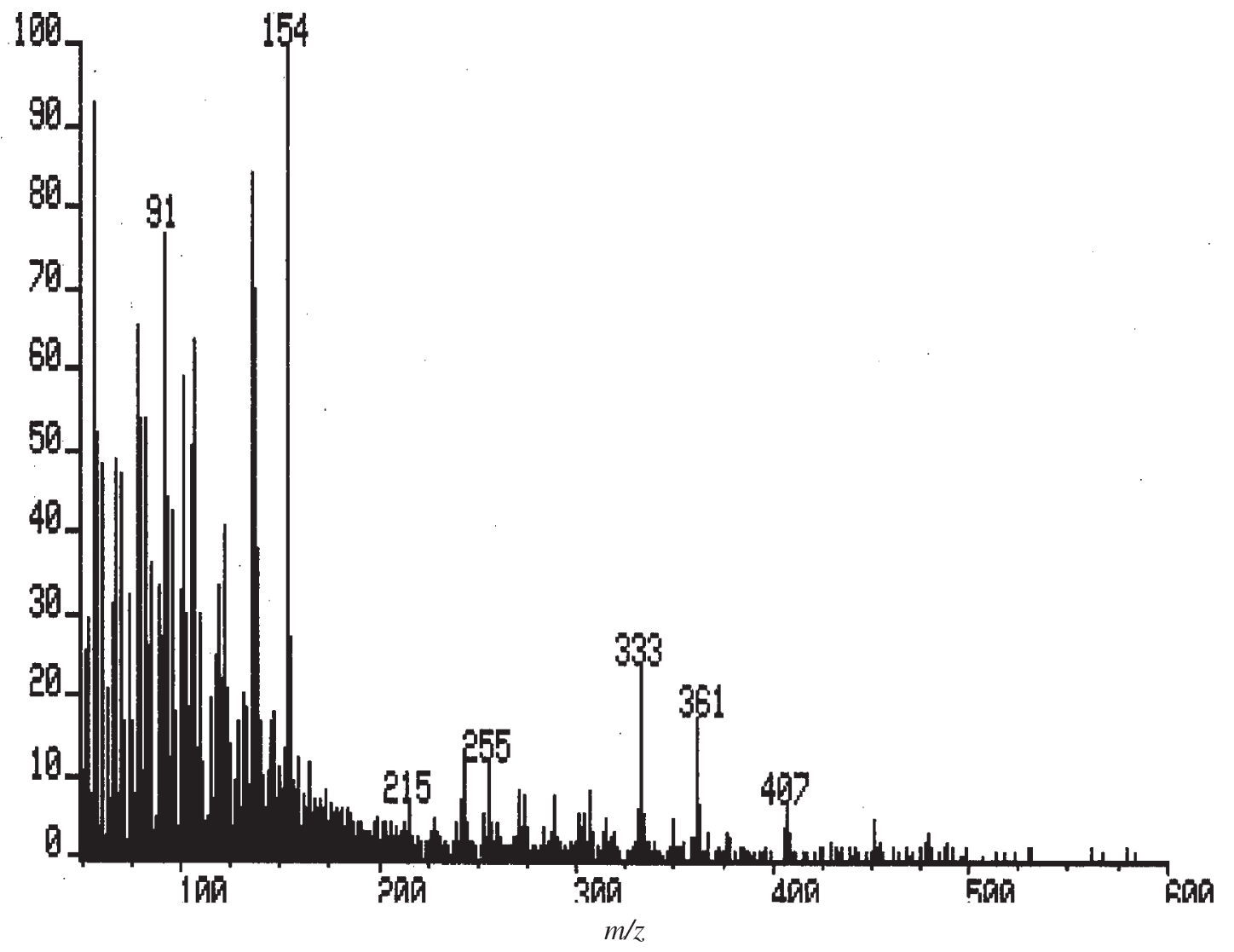

Figure S9. ESIMS for compound 5. 


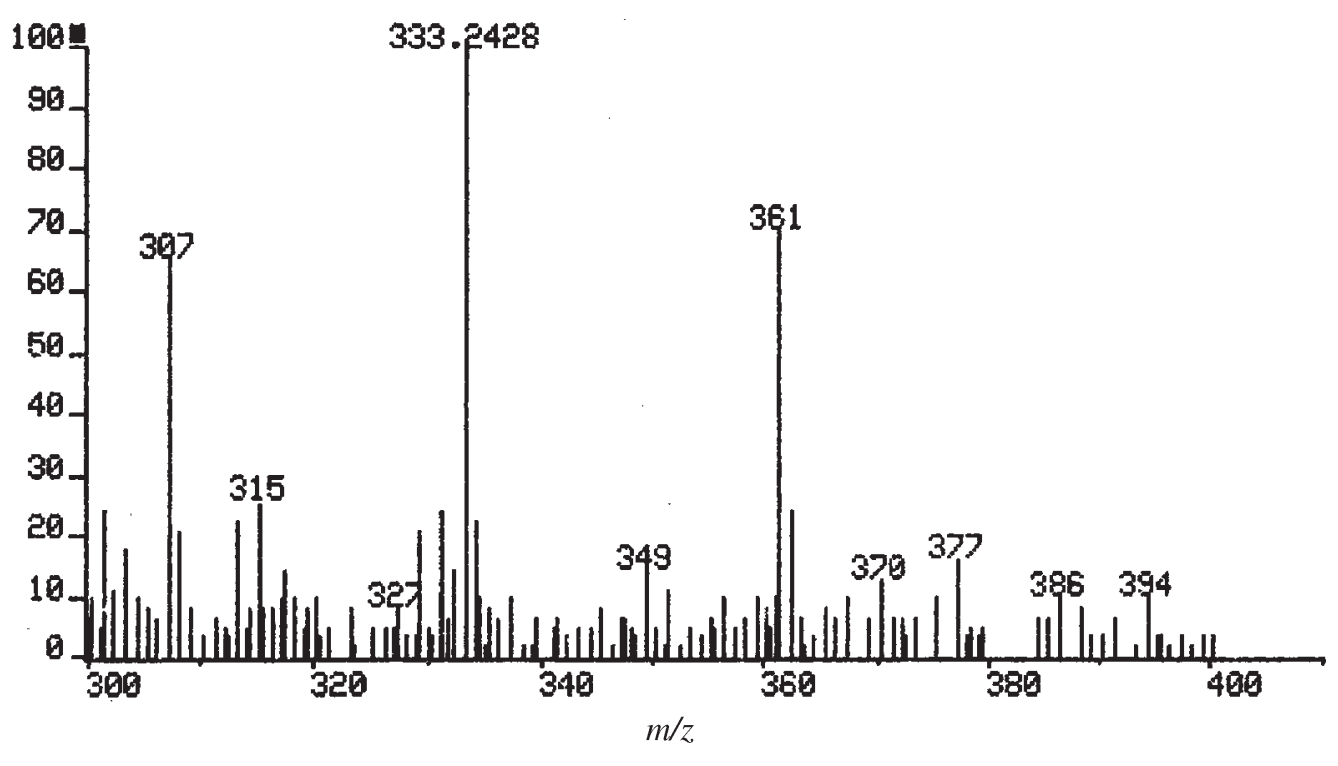

Figure S10. HRESIMS for compound 5.
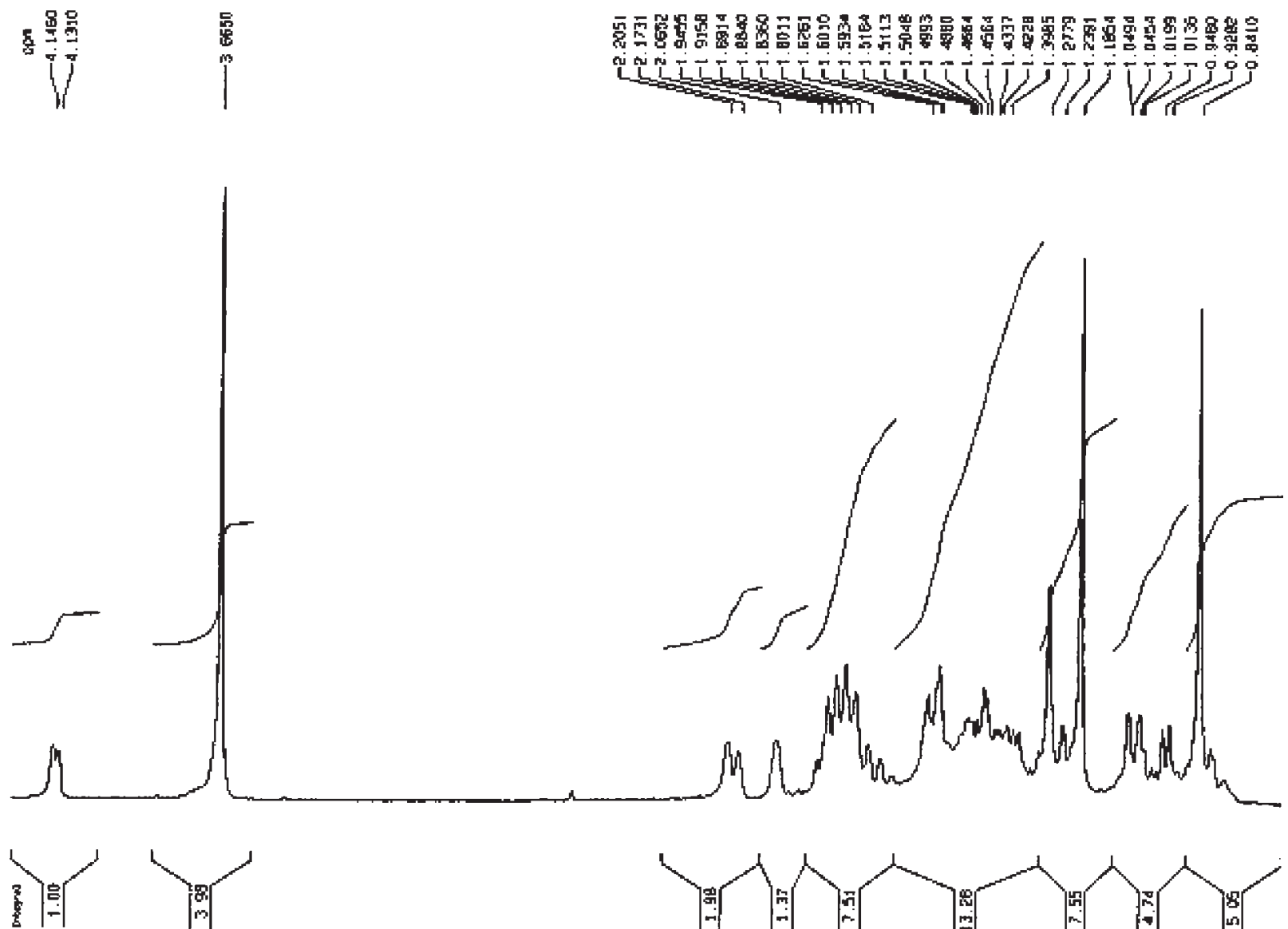


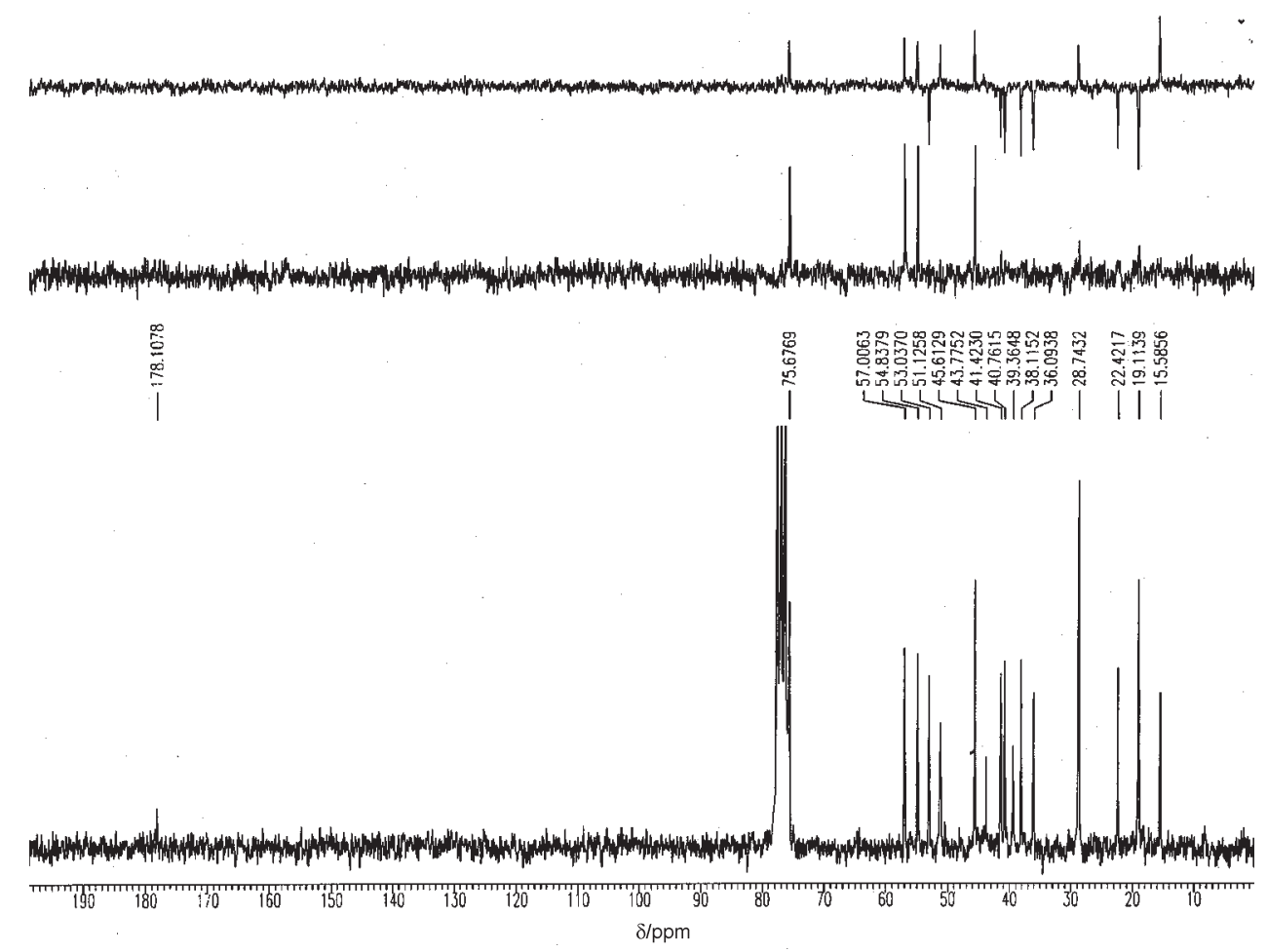

Figure S12. ${ }^{13} \mathrm{C}$ NMR, DEPT 90 and DEPT135 for compound $8\left(50 \mathrm{MHz}, \mathrm{CDCl}_{3}\right)$.

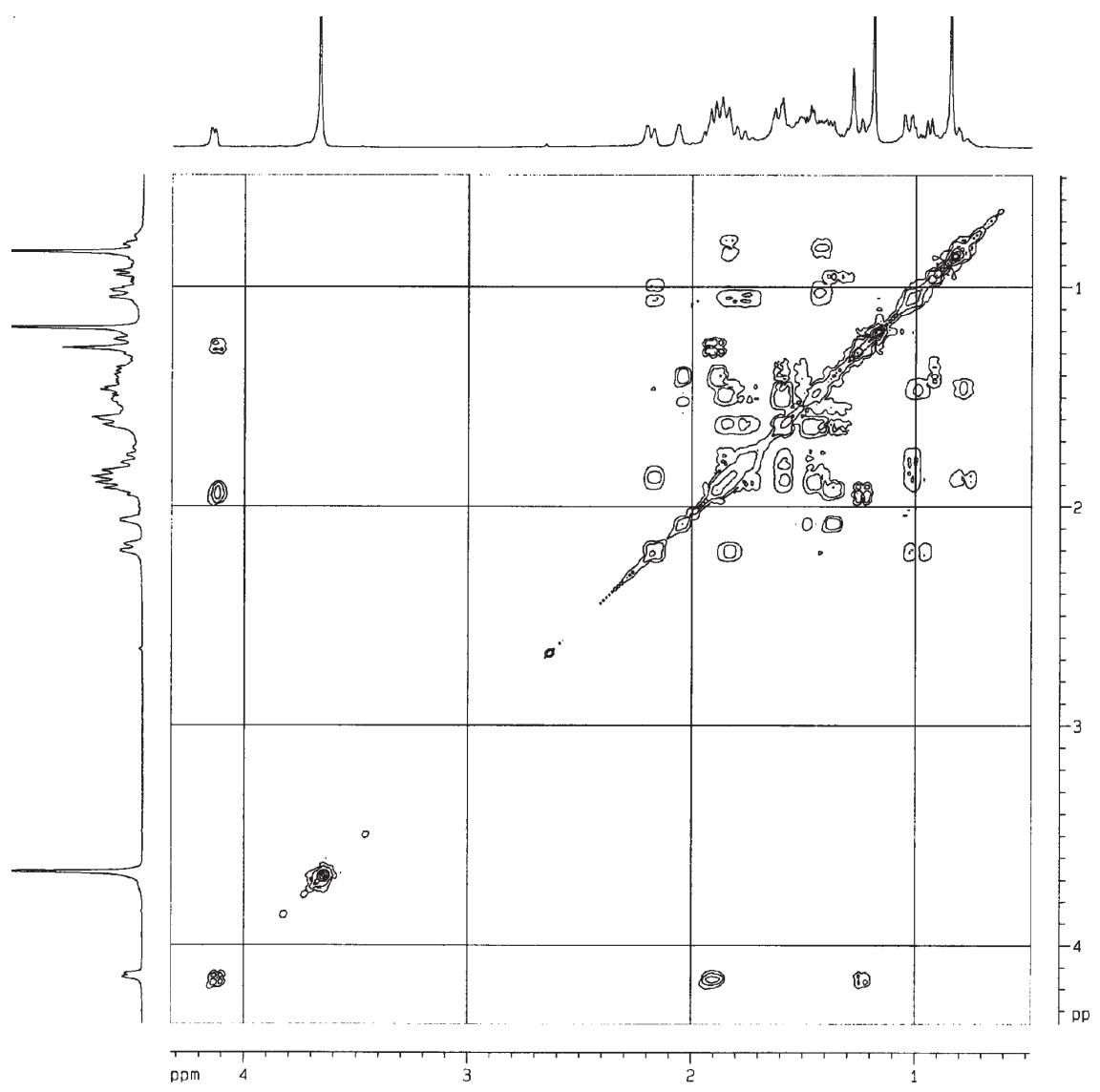

Figure S13. ${ }^{1} \mathrm{H}-{ }^{1} \mathrm{H}$ COSY for compound $8\left(200 \mathrm{MHz}, \mathrm{CDCl}_{3}\right)$. 

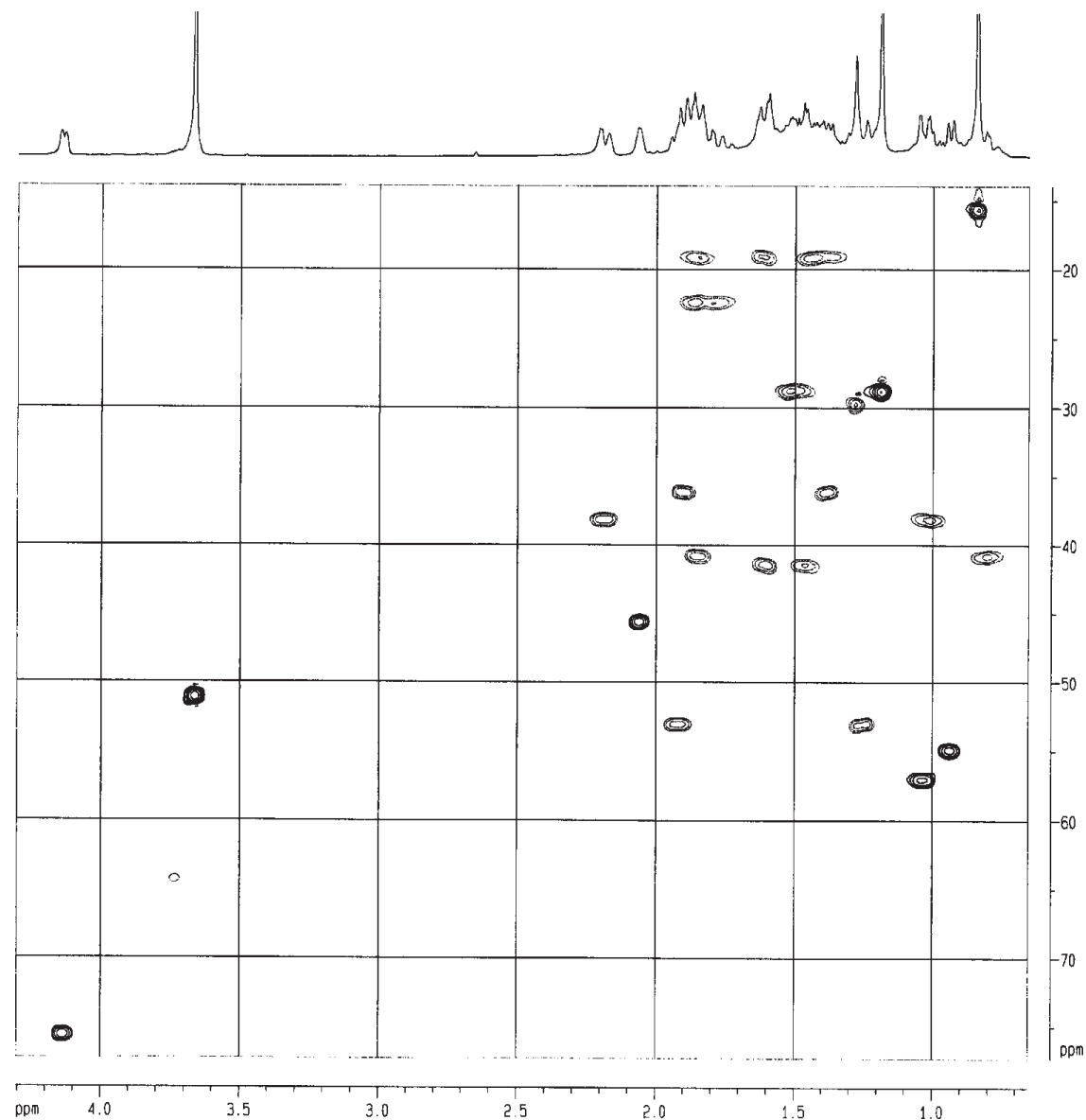

Figure S14. HMQC for compound $8\left({ }^{1} \mathrm{H} /{ }^{13} \mathrm{C} \mathrm{NMR} 200 \mathrm{MHz} / 50 \mathrm{MHz}, \mathrm{CDCl}_{3}\right)$.

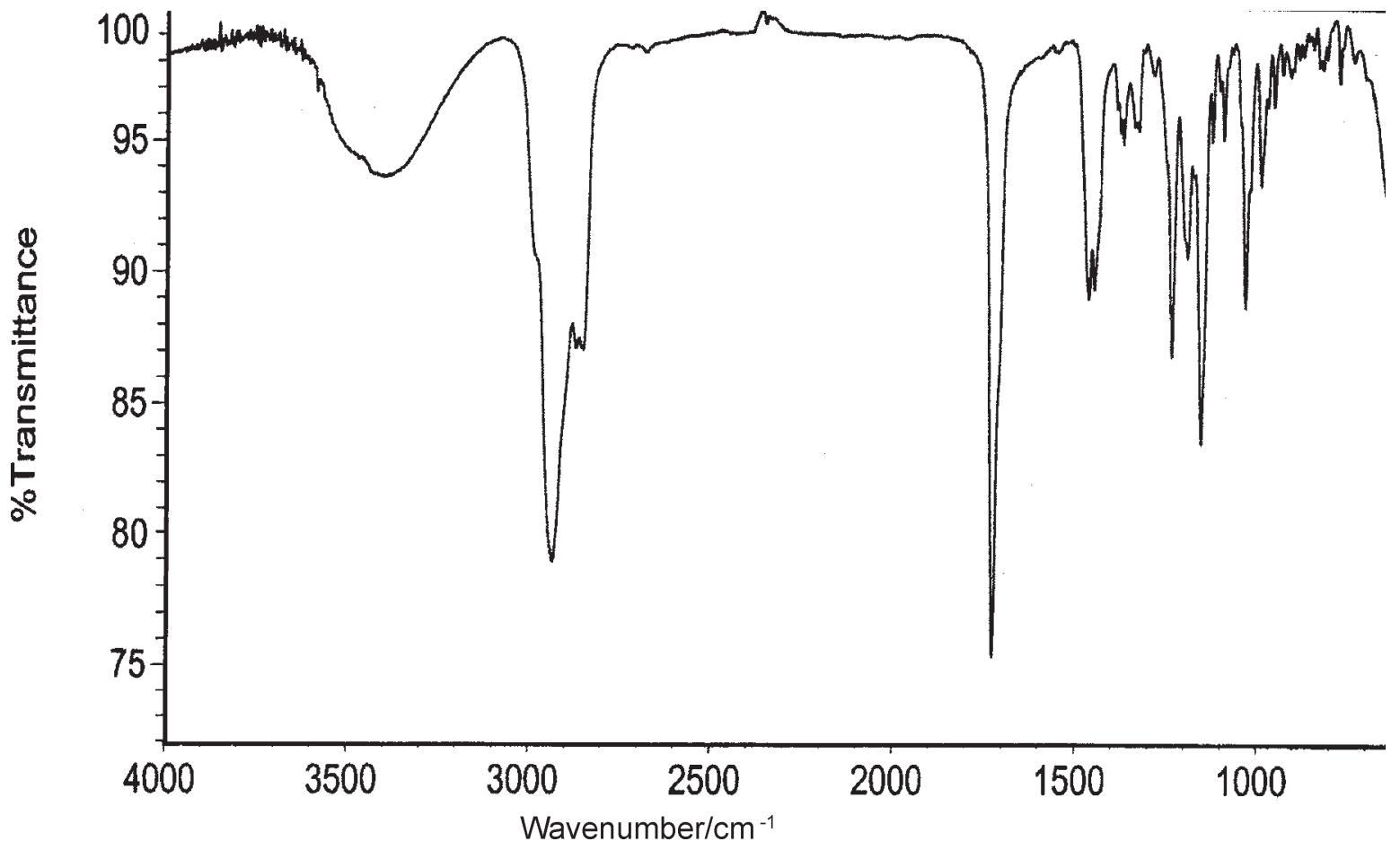

Figure S15. IR for compound 8 . 


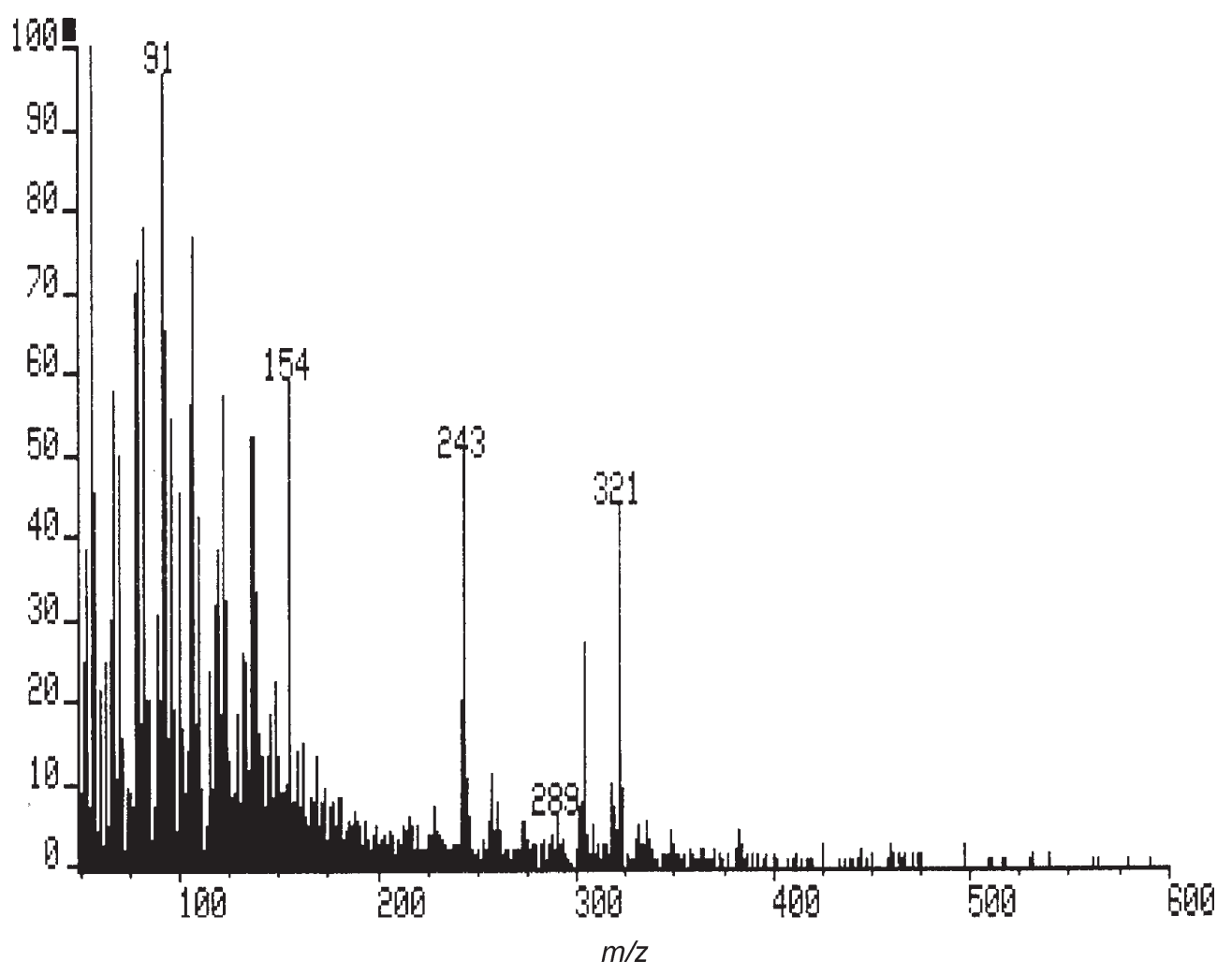

Figure S16. ESIMS for compound 8.

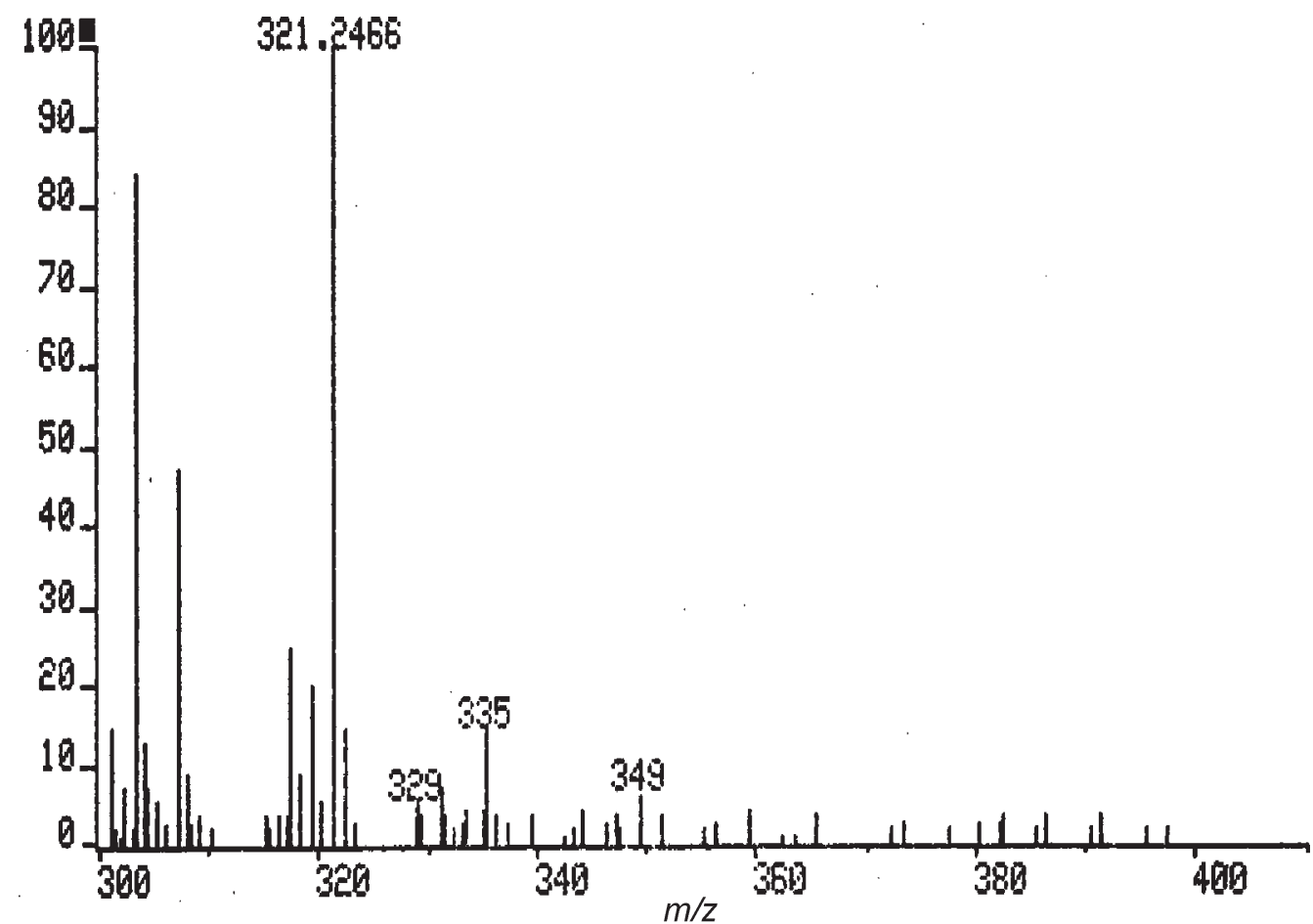

Figure S17. HRESIMS for compound 8. 